\title{
Status of adjuvant endocrine therapy for breast cancer
}

Gaia Schiavon ${ }^{1,2^{*}}$ and lan E Smith ${ }^{1,2}$

\begin{abstract}
Adjuvant endocrine therapy reduces the risk of recurrence and death from breast cancer in women with hormone receptor-positive early breast cancer. Tamoxifen has been the standard therapy for decades, and this is still the case for pre-menopausal women. Ovarian suppression is of similar efficacy but currently there is no strong evidence for adding this to tamoxifen and the additional morbidity can be considerable. Results from two important trials addressing this issue are imminent. In post-menopausal women, aromatase inhibitors (Als) (letrozole, anastrozole, or exemestane) are superior to tamoxifen in preventing recurrence but only letrozole has been shown to improve survival. The main gain is against high-risk cancers, and tamoxifen gives very similar benefit for low-risk disease. Traditionally, treatment has been given for around 5 years, but many women remain at risk of relapse for 10 years or more. The Als, and more recently tamoxifen, have been shown to reduce further the risk of late recurrence in women still in remission after 5 years of tamoxifen if given for a further 5 years. The comparative benefits of these two options and the selection of patients most likely to benefit from long-term adjuvant endocrine therapy are important topics for further research, as is the optimum duration of Al therapy started upfront.
\end{abstract}

\section{Introduction}

Adjuvant endocrine therapy, usually today with tamoxifen or an aromatase inhibitor (AI), is standard treatment for estrogen receptor-positive $\left(E R^{+}\right)$, early-stage breast cancer (BC), which accounts for approximately $75 \%$ of $B C$ [1]. This is by far the oldest effective systemic treatment for any cancer, and Figure 1 illustrates the

\footnotetext{
* Correspondence: gaia.schiavon@icr.ac.uk

${ }^{1}$ The Royal Marsden NHS Foundation Trust, Breast Unit, Fulham Road, London SW3 6JJ, UK

${ }^{2}$ The Institute of Cancer Research, 237 Fulham Road, London SW3 6JB, UK
}

evolution of endocrine therapy, starting with Thomas William Nunn in the 1880s [2].

\section{First trials: oophorectomy}

Oophorectomy - or ovarian ablation (OvA) - was the first form of systemic treatment for $\mathrm{BC}$ [3]. Although the interpretation of many trials testing OvA is limited by the small sample size or study design, their combined analysis (using age as a surrogate for menopausal status) through the Early Breast Cancer Trialists' Collaborative Group (EBCTCG) has unequivocally established that OvA as a single intervention reduces recurrence and increases survival for women younger than 50 years of age for both axillary node-positive and node-negative disease [4]. By indirect comparison, the magnitude of the benefit was similar to that seen with adjuvant chemotherapy or tamoxifen (see below) [5,6].

\section{Adjuvant tamoxifen}

\section{First trials}

Results of the first randomized trials - Nolvadex Adjuvant Trial Organization, Cancer Research Campaign Adjuvant Breast Trial, National Surgical Adjuvant Breast and Bowel Project (NSABP) B-14 - showing the benefit of tamoxifen as adjuvant treatment in early $\mathrm{BC}$ are shown in Figure 1 [7-11].

\section{Tamoxifen and the Oxford overview}

The first Oxford EBCTCG meta-analysis involved almost 30,000 women in 28 trials with either nodepositive or node-negative $\mathrm{BC}$ who were randomly assigned to tamoxifen (or not) for about 5 years [12]. It demonstrated a clear reduction in mortality in women at least 50 years of age treated with tamoxifen $(P<0.0001)$ and a reduction in the annual odds of death during the first 5 years of about $20 \%$. Subsequent analyses showed that the proportional risk reductions produced by tamoxifen were little affected by entry age or nodal status [13]. 


\begin{tabular}{|c|c|c|}
\hline \multirow[b]{2}{*}{1882} & \multicolumn{2}{|r|}{ First Observations / Trials - Oophorectomy } \\
\hline & $\begin{array}{ll}\text { Thomas } & \text { William } \\
\text { Nunn [2] } & \end{array}$ & $\begin{array}{l}\text { Case history of a perimenopausal woman whose } \mathrm{BC} \text { regressed } 6 \text { months after her menstruation ceased: } \\
\text { first recognition of the relationship of ovarian function to } \mathrm{BC}\end{array}$ \\
\hline 1889 & Schinzinger [3] & $\begin{array}{l}\text { First proposed theory of surgical oophorectomy-for-cancer both for advanced disease and as } \\
\text { prophylaxis against local recurrence }\end{array}$ \\
\hline 1896 & Beatson [3] & $\begin{array}{l}\text { Surgical oophorectomy in metastatic patient who was possibly in the luteal phase of her menstrual } \\
\text { cycle }\end{array}$ \\
\hline 1897 & Boyd [3] & Surgical oophorectomy as adjuvant treatment (5 cases) \\
\hline 1952 & Huggins [3] & Adrenalectomy (1966 wins Nobel Prize for development of endocrine therapy) \\
\hline 1959 & Paterson [4] & First randomised trial of OvA for $\mathrm{EBC}$ \\
\hline \multirow[t]{2}{*}{ (1996) } & $\begin{array}{l}\text { EBCTCG } \\
\text { meta-analysis [4-6] }\end{array}$ & $\begin{array}{l}12 \text { randomised trials began before } 1990 \text { including } 3456 \text { women receiving OvA or OvS vs control*. } \\
\text { OvA as a single intervention reduces recurrence and increases survival for women }<50 \mathrm{yr} \text { of age both } \\
\text { for node-positive and node-negative. } \\
\text { - } 15 \text {-yr survival significantly improved with OvA ( } 52.4 \text { vs } 46.1 \%, 6.3 \text { fewer deaths per } 100 \text { women, } \\
\text { logrank } 2 \mathrm{p}=.001 \text { ) } \\
\text { - RFS ( } 45.0 \text { vs } 39.0 \%, 2 \mathrm{p}=.0007) \\
\text { By indirect comparison: magnitude of benefit similar to that seen with adjuvant chemotherapy or } \\
\text { tamoxifen }\end{array}$ \\
\hline & \multicolumn{2}{|r|}{ First Randomised Trials - Tamoxifen } \\
\hline $1977-83$ & NATO $[7,8]$ & $\begin{array}{l}\text { 1285 women randomised to tamoxifen } 10 \mathrm{mg} \text { BD for } 2 \text { yr or no further treatment. At a median follow- } \\
\text { up of } 5.6 \text { yr tamoxifen-treated patients had: } \\
\text { - } 36 \% \text { reduction in risk of event }(\chi 2=17.69, \mathrm{P}=.0001) \\
\text { - } 29 \% \text { reduction in the risk of death from all causes }(\chi 2=7.48, \mathrm{P}=.006)\end{array}$ \\
\hline 1981-88 & $\begin{array}{l}\text { CRC Adjuvant } \\
\text { Breast Trial [9] }\end{array}$ & $\begin{array}{l}\text { women randomized to: (a) control - no further therapy, (b) tamoxifen 10mg BD for } 2 \mathrm{yr} \text {, (c) } \\
\text { cyclophosphamide i.v. for } 6 \text { days post-operatively, (d) combination - tamoxifen and } \\
\text { cyclophosphamide. } \\
2230 \text { Magnitude of the effect of adjuvant tamoxifen was comparable with that associated with } \\
\text { adjuvant cytotoxic chemotherapy at a similar follow-up time, especially in strongly ER+ve tumors } \\
\text { - Minimal toxicity and excellent compliance }\end{array}$ \\
\hline $1982-98$ & $\begin{array}{l}\text { NSABP B-14 Trial } \\
{[10,11]}\end{array}$ & $\begin{array}{l}\text { Adjuvant tamoxifen in } 2644 \text { women with node-negative } E R+v e ~ B C \text { randomized to tamoxifen } 10 \mathrm{mg} \\
\text { BD vs placebo for } 5 \mathrm{yr} \text {. At } 15 \mathrm{yr} \text { of follow-up tamoxifen-treated patients had: } \\
\text { - significantly better RFS ( } 78 \text { vs } 65 \%, \mathrm{P}<.0001 \text { ) vs placebo } \\
\text { - } \text { significantly better OS ( } 71 \mathrm{vs} 65 \%, \mathrm{P}=.0008 \text { ) vs placebo } \\
\text { Tamoxifen benefit was independent from of age, menopausal status, or tumour ER concentration. For } \\
\text { either outcome measure: } \\
\text { - in women }<50 \mathrm{yr} \text { and } \geq 60 \text { yr tamoxifen benefit was significant for each of the endpoints } \\
\text { - in women aged } 50-59 \mathrm{yr} \text {, there was significant benefit of tamoxifen for RFS, but not for OS }\end{array}$ \\
\hline $\begin{array}{l}\text {; } \text {; EBC, } \\
\text { Adjuvo } \\
\text { rence- }\end{array}$ & $\begin{array}{l}\text { ine therapy histor } \\
\text { arian ablation (OvA) } \\
\text { xic therapy and for } \\
\text { imen (after OvA, in } \\
\text { cancer; EBCTCG, Ea } \\
\text { anization; NSABP, N } \\
\text { yr, year (s). }\end{array}$ & $\begin{array}{l}\text { : the first key steps. The first steps in the evolution of endocrine therapy are presented. *In } \\
\text { and control groups received no routine cytotoxic chemotherapy, in one there were random } \\
\text { OvA in a 'factorial' design, and in four both groups were scheduled to receive a common } \\
\text { those allocated this treatment). BC, breast cancer; BD, bis die (twice daily); CRC, Cancer Research } \\
\text { ly Breast Cancer Trialists' Collaborative Group; ER, estrogen receptor; i.V., intravenously; NATO, } \\
\text { ational Surgical Adjuvant Breast and Bowel Project; OS, overall survival; OvS, ovarian suppression; }\end{array}$ \\
\hline
\end{tabular}

Long-term follow-up has greatly strengthened these findings. The most recent meta-analysis with a median follow-up of 13 years showed that, in $\mathrm{ER}^{+}$disease, tamoxifen for about 5 years achieved a reduction of yearly $\mathrm{BC}$ mortality of about a third throughout the first 15 years (rate ratio (RR) 0.70, $P$ $<0.00001)$. The RRs were 0.53 in years 0 to 4 and 0.68 in years 5 to 9 , and there was no subsequent loss of the gains made during the first decade. Over all time periods, the recurrence rate reduction averaged 39\% $(R R=0.61$ for any recurrence, and 0.62 for contralateral disease incidence; both two-sided $P$ $<0.00001)$ [14]. The relapse curves did not converge after year $10(R R=0.97$ in years 10 to 14$)$; therefore, a high proportion of patients receiving tamoxifen for 5 years can be potentially cured. 


\section{Tamoxifen and age, menopausal status, nodal status, size, and grade}

BC mortality was significantly reduced by tamoxifen in each age group with 15-year gains of $10.6 \%, 4.6 \%, 11.7 \%$, and $17.4 \%$, respectively, in the ages at entry of less than 45,45 to 54,55 to 69 , and $\geq 70$ years. Nodal status, tumor grade, and diameter did not materially affect proportional risk reductions, but they were of course predictive of the absolute risk without tamoxifen and hence of the absolute benefit. Local recurrence, contralateral $\mathrm{BC}$ (generally new primary), and distant recurrence were all substantially reduced by tamoxifen (each $P<0.00001$ ).

\section{Tamoxifen with chemotherapy}

There were highly significant recurrence reductions both in the six trials with no chemotherapy $(R R=0.56)$ and in the 14 trials of chemotherapy plus tamoxifen versus the same chemotherapy alone $(R R=0.67)$, and there was a slightly greater effect of tamoxifen in those with greater degrees of ER positivity in both trial categories [13]. Even if chemotherapy was given, tamoxifen was of substantial further benefit (that is, chemotherapy plus tamoxifen was better than chemotherapy alone), producing a further reduction of about a quarter in 10-year recurrence risk, whether it was started concurrently with the chemotherapy $(R R=0.62)$ or after it $(R R=0.71)$. The slight superiority of starting concurrently was, however, not significant, and these tamoxifen trials did not randomize timing. In all regimens, tamoxifen had a substantial effect.

\section{Significance of progesterone receptor}

ER and progesterone receptor (PgR) status were strongly associated. PgR (when measured) was positive in $76 \%$ of $\mathrm{ER}^{+}$and only $21 \%$ of $\mathrm{ER}^{-}$(strictly, ER-poor) disease. Patients with $\mathrm{ER}^{+} \mathrm{PgR} \mathrm{R}^{-}$disease had just as good a proportional benefit with tamoxifen $(R R=0.60)$ as those with $\mathrm{ER}^{+} \mathrm{PgR}^{+}(\mathrm{RR}=0.63)$ (both $\left.2 P<0.00001\right)$. The absolute recurrence reduction at 15 years seemed, if anything, greater in $\mathrm{ER}^{+} \mathrm{PgR}$-poor than in $\mathrm{ER}^{+} \mathrm{PgR}^{+}$disease, perhaps because of the higher background risk of recurrence without treatment.

The $\mathrm{RR}$ was 0.90 for $\mathrm{ER}^{-} \mathrm{PgR}^{+}$disease $(2 P=0.35)$. As assays improve, progressively fewer $\mathrm{BCs}$ are reported as $\mathrm{ER}^{-} \mathrm{PgR}^{+}$where repeat testing on another tissue sample has been recommended, and it is likely that many of these are artefactual.

\section{Tamoxifen in ER-negative and ER-low breast cancer}

Tamoxifen was of no benefit where ER measurement was zero $(R R=0.97$ for any recurrence; $R R=0.94$ for contralateral disease). However, tamoxifen was beneficial at ER concentrations as low as $10 \mathrm{fmol} / \mathrm{mg}$ of cytosol protein with improving efficacy at increasing ER measurements.
Recent guidelines suggest an immunohistochemistry cutoff of $1 \%$ to define a tumor as $\mathrm{ER}^{+}[15]$.

\section{Duration: 5 years or less}

Both direct [13] and indirect [14] comparisons showed greater mortality reduction with approximately 5 versus 2 years of tamoxifen. Reductions in recurrence and mortality during years 0 to 4 were almost as great for shorter treatment duration but were less during years 5 to 9 . Although the combined effects of patient drop-out and drop-in cannot be quantified exactly, the RR for BC death of 0.70 in the meta-analyses of outcome by allocated treatment suggests that in $\mathrm{ER}^{+}$disease full compliance with 5 years of tamoxifen would reduce 15 -year BC mortality rates by at least a third and probably more. The important issue of tamoxifen for more than 5 years is discussed below ('Extended adjuvant endocrine therapy').

\section{Toxicities}

Tamoxifen and the AIs (see below) are generally well tolerated with a low incidence of serious adverse effects (SAEs). The two serious toxicities with tamoxifen are endometrial cancer and thromboembolic events [16]. The increased uterine cancer incidence has an RR of $2.40(P=$ 0.00002 ) without significant effect on other cancers [14].

The uterine cancer risk was strongly correlated with age, with little absolute risk for entry age of less than 45 years or 45 to 54 years. For entry age of 55 to 69 years, 15 -year incidence rates were $3.8 \%$ in the tamoxifen group and $1.1 \%$ in the control group (absolute increase of $2.6 \%$ ). In $\mathrm{ER}^{+}$disease, there were nine deaths in the tamoxifen group and one in the control group from uterine cancer and six versus no deaths from pulmonary embolus (PE) during the first 5 years (but no apparent excess afterwards). A non-significant excess of stroke deaths (3 extra per 1,000 women during the first 15 years, none of which occurred during the treatment period) was balanced by a non-significant shortfall in cardiac deaths (3 fewer per 1,000 women during the first 15 years); so little net effect on overall vascular mortality was recorded. For entry age of younger than 45 years, intercurrent mortality was low, there were no deaths from uterine cancer or PE in either group, and 15-year gains in overall and $\mathrm{BC}$ mortality were similar.

\section{CYP2D6 genotyping and tamoxifen efficacy}

Tamoxifen is metabolized by the cytochrome P450 2D6 (CYP2D6) to 4-hydroxy tamoxifen and 4-hydroxy-Ndesmethyl tamoxifen (endoxifen), the latter metabolite being the more abundant and more potent in terms of ER-binding affinity and suppression of estradiolstimulated cell proliferation $[17,18]$.

Therefore, CYP2D6-mediated metabolism is the ratelimiting enzymatic step for the formation of endoxifen, 
and the association of known genetic and drug factors influencing CYP2D6 enzyme activity with tamoxifen efficacy has been investigated by several groups but with conflicting results [19-24]. Recently, however, two large randomized trials - Arimidex, Tamoxifen, Alone or in Combination (ATAC) and Breast International Group (BIG) 1-98 - have shown that CYP2D6 variant alleles do not influence outcome on tamoxifen [21,22,25], and it is our view that there is no clinical indication for measuring these alleles in patients about to receive tamoxifen.

\section{Adjuvant ovarian suppression}

The 2005 Oxford Overview (but not the most recent in 2011) included 7,601 women (age of less than 50 years) treated with either OvA (approximately 55\%) or ovarian suppression (OvS) with the luteinizing hormone-releasing hormone (LHRH) (that is, goserelin) analogue, confirming a reduction of approximately $30 \%$ in recurrence and BC mortality [13]. The real benefit may be greater because many of the women in these trials had unknown receptor status. The risk reduction for women younger than 40 years was not significantly different from those who were 40 to 49. There was no significant difference in efficacy between OvA and OvS, despite a slight trend against the LHRH analogues. The benefit of OvA was sustained for up to 15 years, and an absolute difference in recurrence rate was $4.3 \%$. This questions whether relatively short LHRH analogue treatment used today for no more than 2 to 3 years is as effective as permanent ablation.

A more detailed systematic review focused on 16 adjuvant randomized trials using LHRH agonists in 9,022 patients with hormone receptor-positive $\left(\mathrm{HR}^{+}\right) \mathrm{BC}(91.8 \%$ were $\mathrm{ER}^{+}$and the remainder were $\mathrm{ER}^{-} \mathrm{PgR}^{+}$) [26]. In these trials, women were randomly assigned to receive an LHRH agonist or not, and other comparisons were based on chemotherapy or tamoxifen. Statistically significant reduction of recurrence (by $13 \%, P=0.02$ ) or death (by $15 \%, P=$ 0.03 ) after recurrence was observed when LHRH was added to agonists to tamoxifen or chemotherapy (or both) but not when used as the only systemic adjuvant treatment.

The relative merits of adjuvant OvS, tamoxifen, or the two treatments combined are still controversial. A US Intergroup trial (INT 0101) randomly assigned 1,503 pre-menopausal women pre-treated with chemotherapy to control arm (no adjuvant endocrine therapy), 5 years of goserelin, or 5 years of goserelin plus tamoxifen [27]. This showed a trend toward improvement in overall survival (OS) for goserelin versus control (hazard ratio $=$ $0.88, P=0.14)$ and a greater benefit for combined goserelin plus tamoxifen versus goserelin (disease-free survival (DFS): hazard ratio $=0.74, P<0.01$ and OS: hazard ratio $=0.91, P=0.21$ ), suggesting that there may be a benefit of adding tamoxifen to goserelin on DFS but not OS.
The Austrian Breast and Colorectal Cancer Study Group (ABSCG)-12, a randomized controlled multicenter trial in 1,803 pre-menopausal women with $\mathrm{HR}^{+} \mathrm{BC}$ (all receiving adjuvant goserelin), compared the efficacy and safety of anastrozole or tamoxifen with or without zoledronic acid for 3 years [28]. Of note, these patients did not receive any adjuvant chemotherapy, although approximately $5 \%$ of patients received neoadjuvant chemotherapy (balanced in the four arms). In regard to the comparison of anastrozole versus tamoxifen, the DFS was not different between the two arms, but patients on anastrozole alone had shorter OS (hazard ratio $=1.75$, $P=0.02$ ) at a median follow-up of 62 months (range of 0 to 114.4 months) [29]. Body mass index had a significant impact on the efficacy of anastrozole plus goserelin in these women [30]. The authors commented that incomplete suppression of estrogen production in peripheral body fat could be the cause of the reduced effect of anastrozole in the overweight and obese groups of patients. Unfortunately, the important clinical question of whether there was any gain in adding goserelin to tamoxifen was not addressed in any of the abovementioned trials.

Long-term follow-up (median of 12 years) of 2,706 women enrolled in the Zoladex In Pre-menopausal Patients trial showed no significant difference between 2 years of tamoxifen treatment versus 2 years of goserelin versus 2 years of combined tamoxifen plus goserelin in reducing the risk for an event (recurrence, new tumor, or death) $(\mathrm{RR}=29 \%, 33 \%$, and $35 \%$, respectively, compared with no endocrine therapy) [31]. The $P$ values for the test of interaction between goserelin and tamoxifen were 0.01 (any event), 0.13 (death from any cause), 0.016 (BC recurrence), and 0.17 (death from $\mathrm{BC}$ ).

Two important ongoing randomized phase 3 trials Suppression of Ovarian Function Trial (SOFT) and Tamoxifen and Exemestane Trial (TEXT) - are evaluating the addition of OvS to tamoxifen and also the role of AIs in pre-menopausal women with $\mathrm{ER}^{+}$early BC. SOFT compares tamoxifen versus OvS plus tamoxifen versus OvS plus exemestane for 5 years. OvS can be achieved with gonadotropin-releasing hormone analog (triptorelin) for 5 years, oophorectomy or ovarian irradiation. TEXT compares 5 years of OvS (triptorelin) plus tamoxifen to OvS (triptorelin) plus exemestane. Primary analyses for both trials are expected in late 2014 to early 2015.

In summary, current data suggest that OvS is equivalent to tamoxifen for patients in whom the latter is contraindicated, but so far there is no conclusive evidence that OvS in addition to tamoxifen, or indeed to chemotherapy, is of superior benefit, and for many women this treatment can have an adverse effect on quality of life. 


\section{Adjuvant aromatase inhibitor trials}

The development of inhibitors of aromatase, the enzyme that synthesizes estrogens from androgens, has provided an alternative strategy to deprive breast tumors of stimulation by endogenous estrogens in post-menopausal women whose ovaries are no longer active and in premenopausal women in whom ovarian function has been suppressed or the ovaries have been removed [32,33]. It is important to note that AIs are ineffective in premenopausal women with functioning ovaries [33].

Aminoglutethimide (AG) was the first AI to be developed for clinical use [34-36] and showed benefit initially in advanced disease and then as adjuvant therapy [37], but it also suppressed aldosterone and had toxicities, including rash and somnolence. A randomized clinical trial involving 2,021 post-menopausal women receiving tamoxifen alone for 5 years or in combination with AG for the first 2 years of treatment showed no significant difference in 5-year DFS and OS [38]. Moreover, more patients failed to complete combination treatment $(13.7 \%)$ because of side effects compared with tamoxifen alone (5.2\%, $P=0.0001)$.

Today three third-generation AIs are approved for use: anastrozole and letrozole are non-steroidal AIs that reversibly and non-covalently bind aromatase [39], and exemestane is a steroidal AI that irreversibly and covalently binds aromatase. All third-generation compounds approach nearly complete suppression of total-body aromatization and plasma estrogen levels [40,41]. In a recent study, letrozole was found to inhibit whole-body aromatization by greater than $99 \%$ in all 12 patients [41] Third-generation AIs have been studied as adjuvant therapy against tamoxifen in a series of randomized clinical trials in post-menopausal women, both as frontline treatment and after tamoxifen (Tables 1 and 2).

\section{Arimidex, tamoxifen, alone or in combination}

The ATAC trial was the first trial to present data comparing adjuvant tamoxifen with an $\mathrm{AI}$, and its results heralded a major change in the endocrine therapy of post-menopausal women. Tamoxifen was compared with anastrozole alone or with anastrozole plus tamoxifen for 5 years in 9,366 post-menopausal women, of whom 7,839 (84\%) were known to be $\mathrm{HR}^{+}$[42]. At a median follow-up of 33.3 months, rates of 3-year DFS of $89.4 \%$ for anastrozole and $87.4 \%$ for the tamoxifen alone (hazard ratio $=0.83, P=0.013$ ) were seen. The combination showed no significant difference to tamoxifen alone (87.2\%, hazard ratio $=1.02, P=0.8$ ). The DFS improvement with anastrozole was seen in $\mathrm{HR}^{+}$but not in $\mathrm{HR}^{-}$ patients. The incidence of contralateral BC was significantly lower with anastrozole than with tamoxifen (odds ratio $0.42, P=0.007$ ).
After a median follow-up of 120 months, the longterm superior efficacy and safety of anastrozole over tamoxifen as initial adjuvant therapy were confirmed [53]. There were significant improvements (both in the whole cohort and in the $\mathrm{HR}^{+}$subgroup) in the anastrozole group compared with the tamoxifen group for DFS, time to recurrence (TTR), and time to distant recurrence (TTDR) (Table 2). In $\mathrm{HR}^{+}$patients, absolute differences in TTR between anastrozole and tamoxifen increased over time $(2.7 \%$ at 5 years and $4.3 \%$ at 10 years) and recurrence rates remained significantly lower on anastrozole than tamoxifen after treatment completion (hazard ratio $=0.81, P=0.03$ ), although the carryover benefit was smaller after 8 years. There was, however, no significant difference in OS (hazard ratio = $0.95, P=0.4$ ) or in deaths after recurrence between anastrozole and tamoxifen.

\section{Breast international group 1-98}

The BIG 1-98 study involved the other third-generation non-steroidal AI, letrozole, and compared 5 years of monotherapy with tamoxifen or with letrozole or with sequences of 2 years of one of these agents followed by 3 years of the other. The primary core analysis included all 8,010 patients but did not include any events after the first 2 years (the time of the switch) for patients in the two sequential arms [43]. These results showed that letrozole improved DFS and TTDR versus tamoxifen alone. After a median follow-up of 25.8 months, 5-year DFS estimates were $84.0 \%$ and $81.4 \%$, respectively. Compared with tamoxifen, letrozole significantly reduced the risk of a DFS event (hazard ratio $=0.81, P=0.003$ ) and the risk of distant recurrence (hazard ratio $=0.73, P=0.001$ ).

The OS analysis of this trial was problematic as patients on the tamoxifen-alone arm were given the option to cross over to letrozole once initial results became available. Different analytical tools were developed to overcome this, including inverse probability of censoring weighted (IPCW) analysis, which achieves better estimates of relative treatment effects in the presence of selective crossover [58,59]. At a median follow-up of 8.7 years from random assignment, letrozole monotherapy was confirmed to be significantly better than tamoxifen, not just for DFS but (in contrast to ATAC) for OS by both intention to treat (ITT) and IPCW analysis (Table 2) [54].

\section{Sequential aromatase inhibitor treatment after tamoxifen} Several trials - including Intergroup Exemestane Study (IES), Arimidex-Nolvadex 95, ABCSG-8, and the Italian Tamoxifen Anastrozole trial - have addressed the issue of switching to an AI after 2 to 3 years of tamoxifen in post-menopausal women with $\mathrm{ER}^{+}$disease [46-49]. These have consistently shown benefit for the switch and indeed tended to have lower hazard ratios for DFS 
Table 1 Main prospective, randomized, phase III clinical trials testing adjuvant aromatase inhibitors

\begin{tabular}{|c|c|c|c|c|c|}
\hline Study & Design & Arms & Number & Population (post-menopausal women) & $\begin{array}{c}\text { Primary } \\
\text { endpoint (s) }\end{array}$ \\
\hline \multicolumn{6}{|c|}{ Monotherapy (versus tamoxifen) } \\
\hline ATAC [42] & Double-blind & $A$ versus $T$ versus $T+A$ (5 years) & 9,366 & $\mathrm{HR}^{+} \mathrm{EBC}$ & $\begin{array}{l}\mathrm{DFS}^{\mathrm{a}} \text {, occurrence } \\
\text { of AEs }\end{array}$ \\
\hline BIG 1-98 [43] & Double-blind & $\begin{array}{c}L \text { versus } T \text { versus } L \rightarrow T \text { versus } T \rightarrow L \\
\text { (5 years) }\end{array}$ & 8,010 & $\mathrm{HR}^{+} \mathrm{EBC}$ & $\mathrm{DFS}^{\mathrm{b}}$ \\
\hline \multirow[t]{2}{*}{ TEAM $[44,45]$} & \multirow{2}{*}{$\begin{array}{l}\text { Open-label, } \\
\text { multinational }\end{array}$} & Upfront T versus E (2.75 years) & 9,775 & $\mathrm{HR}^{+} \mathrm{EBC}$ & $\mathrm{DFS}^{\mathrm{C}}$ \\
\hline & & Sequential $\mathrm{T} \rightarrow \mathrm{E}$ versus $\mathrm{E}$ (5 years) & & & \\
\hline
\end{tabular}

\begin{tabular}{|c|c|c|c|c|c|}
\hline \multicolumn{6}{|c|}{ Sequential therapy } \\
\hline IES [46] & Double-blind & $\mathrm{T} \rightarrow \mathrm{E}$ versus $\mathrm{T} \rightarrow \mathrm{T}$ (5 years) & 4,724 & $\mathrm{HR}^{+} \mathrm{EBC}$ & $\mathrm{DFS}^{\mathrm{d}}$ \\
\hline ARNO 95 [47] & Open-label & $\begin{array}{c}\mathrm{T}(2 \text { years }) \rightarrow \text { earsabears }) \text { versus } T \\
(2 \text { years }) \rightarrow T(3 \text { years })\end{array}$ & 979 & $\mathrm{HR}^{+} \mathrm{EBC}$ who received 2 years of $\mathrm{T}$ & $\mathrm{DFS}^{\mathrm{a}}$ \\
\hline $\begin{array}{l}\text { ABCSG Trial } 8 \\
{[48]}\end{array}$ & Open-label & $\begin{array}{c}\text { T (5 years) versus } T(2 \text { years }) \rightarrow A \\
\text { ( } 3 \text { years })\end{array}$ & 3,714 & $\mathrm{HR}^{+} \mathrm{EBC}$ who received $2-3$ years of $\mathrm{T}$ & $\mathrm{RFS}^{\mathrm{e}}$ \\
\hline ITA [49] & $\begin{array}{l}\text { Open-label, multi- } \\
\text { center }\end{array}$ & $\begin{aligned} \mathrm{T}(2-3 \text { years }) & \rightarrow \mathrm{A}(5 \text { years }) \text { versus } \mathrm{T} \\
& (5 \text { years })\end{aligned}$ & 448 & $\begin{array}{l}\mathrm{HR}^{+} \text {(or unknown) node } \mathrm{EBC} \text { who } \\
\text { received 2-3 years of } \mathrm{T}\end{array}$ & RFS $^{f}$ \\
\hline BIG 1-98 [43] & Double-blind & $\begin{array}{c}L \text { versus } T \text { versus } L \rightarrow T \text { versus } T \rightarrow L \\
\text { (5 years) }\end{array}$ & 8,010 & $\mathrm{HR}^{+} \mathrm{EBC}$ & $\mathrm{DFS}^{\mathrm{b}}$ \\
\hline \multirow[t]{2}{*}{ TEAM [44] } & \multirow{2}{*}{$\begin{array}{l}\text { Open-label, } \\
\text { multinational }\end{array}$} & Upfront E (2.75 years) versus T & \multirow[t]{2}{*}{9,779} & \multirow[t]{2}{*}{$\mathrm{HR}^{+} \mathrm{EBC}$} & \multirow[t]{2}{*}{$\mathrm{DFS}^{\mathrm{c}}$} \\
\hline & & $\mathrm{E}$ (5 years) versus sequential $\mathrm{T} \rightarrow \mathrm{E}$ & & & \\
\hline
\end{tabular}

\begin{tabular}{|c|c|c|c|c|c|}
\hline \multicolumn{6}{|c|}{ Extended therapy } \\
\hline MA.17 [50] & Double-blind & L versus placebo & 5,187 & $\begin{array}{c}\mathrm{HR}^{+} \mathrm{EBC} \text { who had received } 4.5 \text { to } 6 \text { years } \\
\text { of adjuvant } \mathrm{T} \text { therapy }\end{array}$ & $\mathrm{DFS}^{\mathrm{g}}$ \\
\hline $\begin{array}{l}\text { ABCSG Trial 6a } \\
{[51]}\end{array}$ & Open-label & $\begin{array}{c}\text { A (3 years) versus no further } \\
\text { treatment }\end{array}$ & 856 & $\begin{array}{l}\mathrm{HR}^{+} \mathrm{EBC} \text { who had received } 5 \text { years of } \\
\text { adjuvant } \mathrm{T} \text {, with or without } \mathrm{AG} \text {, for the } \\
\text { first } 2 \text { years of therapy }\end{array}$ & RFS $^{h}$ \\
\hline SABP-33 [52] & Double-blind & $\begin{array}{l}\text { E (5 years) versus placebo } \\
\text { (5 years) }\end{array}$ & 1,598 & $\begin{array}{l}\mathrm{HR}^{+} \mathrm{T} 1-3 \mathrm{~N} 1 \mathrm{M} 0 \mathrm{EBC} \text { who were disease-free } \\
\text { after } 5 \text { years of adjuvant } \mathrm{T}\end{array}$ & $\mathrm{DFS}^{\mathrm{a}}$ \\
\hline
\end{tabular}

\begin{abstract}
${ }^{a}$ Time from random assignment to the occurrence of local or distant recurrence, new contralateral breast cancer, or death from any cause; ${ }^{b}$ time from random assignment to the first of the following events: invasive recurrence in local, regional, or distant sites; a new invasive cancer in the contralateral breast; any second (non-breast) primary cancer; or death without a previous cancer event; ctimes from random assignment to the earliest documentation of disease relapse (locoregional or distant tumor recurrence or ipsilateral or contralateral breast cancer) or death from any cause; ${ }^{d}$ time from random assignment to local or distant breast cancer recurrence, new primary breast cancer, or death without recurrence (intercurrent death); ${ }^{~}$ time from random assignment to the earliest occurrence of local or distant recurrence or death as a result of any cause; ${ }^{f}$ time from random assignment to disease recurrence, including both locoregional and distant recurrences (except contralateral breast cancer); ${ }^{9}$ time from random assignment to the recurrence of the primary disease (in the breast, chest wall, or nodal or metastatic sites) or the development of a new primary breast cancer in the contralateral breast; ${ }^{h_{i n t e r v a l}}$ between the start of treatment or of the observation period and the first evidence of locoregional recurrence, contralateral breast cancer, or distant metastasis. $\rightarrow$, switch to; A, anastrozole; ABCSG, Austrian Breast and Colorectal Cancer Study Group; AE, adverse event; AG, aminoglutethimide; ARNO 95, Arimidex-Nolvadex 95; ATAC, Arimidex, Tamoxifen, Alone or in Combination; BIG, Breast International Group; DFS, disease-free survival; E, exemestane; EBC, early breast cancer; HR, hormone receptor; IES, Intergroup Exemestane Study; ITA, Italian Tamoxifen Anastrozole (trial); L, letrozole; NSABP, National Surgical Adjuvant Breast and Bowel Project; RFS, recurrence-free survival; T, tamoxifen; TEAM, Tamoxifen Exemestane Adjuvant Multinational.
\end{abstract}

than direct upfront comparisons of ATAC and BIG 1-98 (Tables 1 and 2). This led to the hypothesis that perhaps a greater gain might be achieved by starting with tamoxifen and switching rather than starting with an AI.

However, this comparison was made directly through random assignment in both the BIG 1-98 and the Tamoxifen Exemestane Adjuvant Multinational (TEAM) (see below) trials and neither has shown any basis for this hypothesis. In BIG 1-98, at a median follow-up of 8.0 years from random assignment, there was no significant difference between one of the crossover arms (tamoxifen followed by letrozole) versus letrozole alone, but there was a trend against starting with tamoxifen and then switching (DFS hazard ratio $=1.07$; OS hazard ratio $=$ 1.10; both $P=0.36$; Table 2) [54].

The multicenter TEAM trial, originally designed to examine the efficacy of exemestane versus tamoxifen in $9,779 \mathrm{HR}^{+}$women [44], was revised in 2004, and patients on tamoxifen were switched to exemestane after 2.5 to 3 years, when the IES (Table 1) reported superior results for a switch from tamoxifen to exemestane after 2 to 3 years [45]. At a median follow-up of 5.1 years ( $60 \%$ of patients completed at least 5 years of follow-up), there was no significant difference in outcome between the two groups: DFS rates were $85 \%$ in the sequential arm and $86 \%$ in the exemestane-alone arm (Table 2) 
Table 2 Outcome results in the main phase III clinical trials testing adjuvant aromatase inhibitors

\begin{tabular}{|c|c|c|c|c|c|c|}
\hline Study & Arms & $\begin{array}{l}\text { DFS hazard ratio } \\
(95 \% \mathrm{Cl})\end{array}$ & $\begin{array}{c}\text { TTR or RFS } \\
\text { hazard ratio } \\
(95 \% \mathrm{CI})\end{array}$ & $\begin{array}{l}\text { TTDR or DRFI or } \\
\text { DRFS or DDFS } \\
\text { hazard ratio } \\
(95 \% \mathrm{Cl})\end{array}$ & $\begin{array}{c}\text { BCFI or BCFS } \\
\text { hazard ratio } \\
(95 \% \mathrm{Cl})\end{array}$ & $\begin{array}{l}\text { OS hazard ratio } \\
(95 \% \mathrm{Cl})\end{array}$ \\
\hline \multicolumn{7}{|c|}{ Monotherapy analysis (versus tamoxifen) } \\
\hline \multirow[t]{2}{*}{$\begin{array}{l}\text { ATAC [53] 120- } \\
\text { month follow-up }\end{array}$} & \multirow{2}{*}{$\begin{array}{c}\text { A versus } T \text { versus } \\
T+A \\
\text { (5 years) }\end{array}$} & $\begin{array}{c}0.91(0.83-0.99) \\
P=0.04\end{array}$ & $\begin{array}{c}\text { TTR } 0.84 \\
(0.75-0.93) P=0.001\end{array}$ & $\begin{array}{c}\text { TTDR } 0.87(0.77-0.99) \\
P=0.03\end{array}$ & NA & $\begin{array}{c}0.97(0.88-1.08) \\
P=0.6\end{array}$ \\
\hline & & $\begin{array}{l}\mathrm{HR}^{+} \text {patients } 0.86 \\
(0.78-0.95) P=0.003\end{array}$ & $\begin{array}{c}\mathrm{HR}^{+} \text {patients } 0.79 \\
(0.70-0.89) \\
P=0.0002\end{array}$ & $\begin{array}{l}\mathrm{HR}^{+} \text {patients } 0.85 \\
(0.73-0.98) P=0.02\end{array}$ & & $\begin{array}{l}\mathrm{HR}^{+} \text {patients } 0.95 \\
(0.84-1.06) P=0.4\end{array}$ \\
\hline \multirow[t]{2}{*}{$\begin{array}{l}\text { BIG 1-98 [54] 8.1- } \\
\text { year follow-up }\end{array}$} & \multirow[t]{2}{*}{$L$ versus $T$} & $\begin{array}{c}0.53(0.78-0.96) \\
P=0.007\end{array}$ & \multirow[t]{2}{*}{ NA } & $\begin{array}{c}\text { DRFI } 0.86(0.74-0.998) \\
P=0.047\end{array}$ & $\begin{array}{c}\text { BCFI } 0.86(0.76-0.98) \\
P=0.03\end{array}$ & $\begin{array}{c}0.87(0.77-0.999) \\
P=0.048\end{array}$ \\
\hline & & $\begin{array}{c}\text { IPCW } 0.82(0.74-0.92) \\
P<0.0002\end{array}$ & & $\begin{array}{c}\text { IPCW } 0.79(0.68-0.92) \\
P=0.003\end{array}$ & $\begin{array}{c}\text { IPCW } 0.80(0.70-0.92) \\
P=0.002\end{array}$ & $\begin{array}{c}\text { IPCW } 0.79(0.69-0.90) \\
P<0.0006\end{array}$ \\
\hline $\begin{array}{l}\text { TEAM [45] 2.75- } \\
\text { year follow-up (be- } \\
\text { fore the switch) }\end{array}$ & $\begin{array}{l}\text { Upfront E ( } 2.75 \\
\text { years) versus T }\end{array}$ & $\begin{array}{c}0.89(0.77-1.03) \\
P=0.12\end{array}$ & NA & NA & NA & NA \\
\hline \multicolumn{7}{|c|}{ Sequential therapy analysis } \\
\hline $\begin{array}{l}\text { IES [46] 91-month } \\
\text { follow-up }\end{array}$ & $\begin{array}{c}\mathrm{T} \rightarrow \mathrm{E} \text { versus } \mathrm{T} \rightarrow \\
\mathrm{T}(5 \text { years })\end{array}$ & $\begin{array}{c}0.81(0.72-0.91) \\
\quad P<0.001\end{array}$ & NA & $\begin{array}{c}\text { TTDR } 0.84(0.73-0.97) \\
P=0.01\end{array}$ & $\begin{array}{c}\text { BCFS } 0.81(0.71-0.92) \\
P<0.001\end{array}$ & $\begin{array}{c}0.53(0.75-0.99) \\
P<0.04\end{array}$ \\
\hline $\begin{array}{l}\text { ARNO } 95 \text { [47] 30.1- } \\
\text { month follow-up }\end{array}$ & $\begin{array}{c}T(2 \text { years }) \rightarrow A \\
\text { (3 years) versus } T \\
\text { (2 years) } \rightarrow T \\
\text { (3 years) }\end{array}$ & $\begin{array}{c}0.66(0.44-1.00) \\
P=0.049\end{array}$ & NA & NA & NA & $\begin{array}{c}0.53(0.28-0.99) \\
P=0.045\end{array}$ \\
\hline $\begin{array}{l}\text { ABCSG Trial } 8 \text { [48] } \\
60 \text {-month follow- } \\
\text { up }\end{array}$ & $\begin{array}{c}\mathrm{T} \text { (2 years) } \rightarrow \mathrm{A} \\
\text { (3 years) versus } \mathrm{T} \\
\text { (5 years) }\end{array}$ & $\begin{array}{c}0.91(0.75-1.103) \\
P=0.33\end{array}$ & $\begin{array}{c}\text { RFS } 0.80(0.631- \\
1.013) P=0.06\end{array}$ & $\begin{array}{c}\text { DRFS } 0.78(0.60-0.99) \\
\quad P=0.046\end{array}$ & NA & $\begin{array}{c}0.87(0.64-1.16) \\
P=0.33\end{array}$ \\
\hline $\begin{array}{l}\text { ITA [49] 128- } \\
\text { month follow-up }\end{array}$ & $\begin{array}{c}\mathrm{T}(2-3 \text { years }) \rightarrow \mathrm{A} \\
(5 \text { years }) \text { versus } \mathrm{T} \\
\text { (5 years) }\end{array}$ & NA & $\begin{array}{c}\text { RFS } 0.64(0.44-0.94) \\
P=0.02\end{array}$ & NA & $\begin{array}{c}\text { BCFS } 0.72(0.44-1.17) \\
P=0.2\end{array}$ & $\begin{array}{c}0.79(0.52-1.21) \\
P=0.3\end{array}$ \\
\hline \multirow[t]{2}{*}{$\begin{array}{l}\text { BIG 1-98 [54] 8.1- } \\
\text { year follow-up }\end{array}$} & \multirow[t]{2}{*}{$\begin{array}{c}\mathrm{L} \rightarrow \mathrm{T} \text { versus } \\
\mathrm{T} \rightarrow \mathrm{L} \text { (5 years) }\end{array}$} & $\begin{array}{c}\mathrm{L} \rightarrow \top 1.06(0.91-1.23) \\
\quad P=0.48\end{array}$ & \multirow[t]{2}{*}{ NA } & $\begin{array}{c}\mathrm{L} \rightarrow \text { T DRFI } 1.14(0.92- \\
\text { 1.42) } P=0.24\end{array}$ & $\begin{array}{c}\mathrm{L} \rightarrow \text { T BCFI } 1.10(0.91- \\
1.32) P=0.34\end{array}$ & $\begin{array}{c}\mathrm{L} \rightarrow \mathrm{T} 0.97(0.80-1.19) \\
P=0.79\end{array}$ \\
\hline & & $\begin{array}{c}T \rightarrow L 1.07(0.92-1.25) \\
P=0.36\end{array}$ & & $\begin{array}{c}T \rightarrow L 1.23(0.99-1.53) \\
P=0.06\end{array}$ & $\begin{array}{c}T \rightarrow L 1.16(0.96-1.40) \\
P=0.12\end{array}$ & $\begin{array}{c}T \rightarrow L 1.10(0.90-1.33) \\
P=0.36\end{array}$ \\
\hline $\begin{array}{l}\text { TEAM [55] 5-year } \\
\text { follow-up (after } \\
\text { the switch) }\end{array}$ & $\begin{array}{l}E(5 \text { years) versus } \\
\text { sequential } T \rightarrow E\end{array}$ & $\begin{array}{c}1.06(0.91-1.24) \\
P=0.42\end{array}$ & $\begin{array}{c}\text { RFS } 1.06(0.88-1.28) \\
P=0.53\end{array}$ & NA & NA & $\begin{array}{c}1.00(0.89-1.14) \\
P>0.99\end{array}$ \\
\hline \multicolumn{7}{|c|}{ Extended therapy analysis } \\
\hline \multirow{3}{*}{$\begin{array}{l}\text { MA.17 [56] } \\
\text { 64-month } \\
\text { follow-up }\end{array}$} & \multirow[t]{3}{*}{$L$ versus placebo } & $\begin{array}{c}0.68(0.56-0.83) \\
P<0.001\end{array}$ & \multirow[t]{3}{*}{ NA } & $\begin{array}{c}\text { DDFS } 0.81(0.63-1.04) \\
P=0.09\end{array}$ & \multirow[t]{3}{*}{ NA } & $\begin{array}{c}0.99(0.79-1.24) \\
P=0.83\end{array}$ \\
\hline & & $\begin{array}{c}\text { IPCW } 0.52(0.45-0.61) \\
P<0.001\end{array}$ & & $\begin{array}{c}\text { IPCW } 0.51(0.42-0.61) \\
P<0.001\end{array}$ & & $\begin{array}{c}\text { IPCW } 0.61(0.52-0.71) \\
P<0.001\end{array}$ \\
\hline & & $\begin{array}{c}\text { SCC } 0.58(0.47-0.72) \\
P<0.001\end{array}$ & & $\begin{array}{c}\text { SCC } 0.68(0.52-0.88) \\
P=0.004\end{array}$ & & $\begin{array}{c}\text { SCC } 0.76(0.60-0.96) \\
P=0.02\end{array}$ \\
\hline $\begin{array}{l}\text { ABCSG Trial } 6[51] \\
62.3 \text {-month follow- } \\
\text { up }\end{array}$ & $\begin{array}{l}\text { A (3 years) } \\
\text { versus no further } \\
\text { treatment }\end{array}$ & NA & $\begin{array}{c}\text { RFS } 0.62(0.40-0.96) \\
P=0.031\end{array}$ & $\begin{array}{c}\text { DFRS } 0.53(0.29-0.96) \\
\quad P=0.034\end{array}$ & NA & $\begin{array}{c}0.89(0.59-1.34) \\
P=0.57\end{array}$ \\
\hline $\begin{array}{l}\text { NSABP-33 [52] 30- } \\
\text { month follow-up }\end{array}$ & $\begin{array}{l}\text { E (5 years) versus } \\
\text { placebo ( } 5 \text { years) }\end{array}$ & $0.68 P=0.07$ & RFS $0.44 P=0.004$ & NA & NA & NA \\
\hline
\end{tabular}

$\rightarrow$, switch to; A, anastrozole; ABCSG, Austrian Breast and Colorectal Cancer Study Group; ARNO 95, Arimidex-Nolvadex 95; ATAC, Arimidex, Tamoxifen, Alone or in Combination; BCFI, breast cancer-free interval; BCFS, breast cancer-free survival; BIG, Breast International Group; Cl, confidence interval; DDFS, distant disease-free survival; DFS, disease-free survival; DRFI, distant relapse-free interval; DRFS, distant relapse-free survival; E, exemestane; $\mathrm{HR}^{+}$, hormone receptor-positive; IPCW, Inverse probability of censoring weighted; IES, Intergroup Exemestane Study; ITA, Italian Tamoxifen Anastrozole (trial); L, letrozole; NA, not available; NSABP, National Surgical Adjuvant Breast and Bowel Project; OS, overall survival; RFS, recurrence-free survival; SCC, approach proposed by Shao and colleagues [57]; T, tamoxifen; TEAM, Tamoxifen Exemestane Adjuvant Multinational; TTDR, time to distant relapse; TTR, time to relapse. 
[55], and OS showed no significant difference, being 91\% in both arms. In summary, there is no therapeutic gain in starting with tamoxifen and switching to an AI rather than starting with an AI upfront.

\section{Sequential tamoxifen after an aromatase inhibitor}

The other BIG 1-98 crossover arm also addressed the question of tamoxifen after 2 to 3 years of letrozole. At a median follow-up of 8.0 years from random assignment, there was no significant difference between letrozole followed by tamoxifen versus letrozole alone (DFS hazard ratio $=1.06, P=0.48$; OS hazard ratio $=0.97, P=$ 0.79; Table 2) [54]. Therefore, the clinical implication is that a woman who wishes to switch from an AI to tamoxifen after 2 to 3 years because of side effects or for whatever reason can do so without adversely affecting outcome, at least for up to 5 years of treatment.

\section{Aromatase inhibitor toxicities and comparative toxicities with tamoxifen}

AIs are associated with a higher incidence of musculoskeletal adverse events (MSAEs) (for example, myalgias and arthralgias), bone fractures, and decreased bone mineral density (BMD) [44,60-67]. In contrast, tamoxifen is associated with a higher incidence of thromboembolic and gynecological events (including endometrial cancer) $[44,55,60,68-70]$. Table 3 summarizes the incidence of treatment-related SAEs in the main adjuvant trials comparing AIs with tamoxifen.

In the 10-year analysis of ATAC, fractures were more frequent during active treatment in the anastrozole versus tamoxifen arm (451 versus $351, \mathrm{OR}=1.33$, $P<0.0001)$ but were similar in the post-treatment follow-up period (110 versus $112, \mathrm{OR}=0.98, P=0.9$ ). Treatment-related SAEs were less common on anastrozole than on tamoxifen (223 versus $369, \mathrm{OR}=0.57$, $P<0.0001)$ but were similar after treatment completion (66 versus $78, \mathrm{OR}=0.84, P=0.3$ ). Anastrozole was associated with significantly less risk of endometrial cancer than tamoxifen $(P=0.02)$. No significant differences in non- $\mathrm{BC}$ deaths or in the incidence of other cancers were found between groups.

In the BIG 1-98 trial, the incidence of treatment discontinuation $(13.6 \%$ versus $11.9 \%$ of patients on letrozole and tamoxifen, respectively, $P=0.08$ ) as a result of an adverse event $(\mathrm{AE})$ was greatest during the first 2 years of treatment and stabilized to an additional $1 \%$ to $2 \%$ per year for the remainder of the 5-year period. Endometrial cancer was diagnosed during treatment in 4 $(0.2 \%)$ versus $11(0.6 \%)$ patients on tamoxifen and letrozole, respectively. No significant difference between the two arms was observed regarding (non-breast) malignancies or deaths without prior cancer events.
In the TEAM study, generally, gynecological symptoms and PE occurred more frequently in the sequential treatment group than in the exemestane-only group and the opposite was seen regarding the incidence of MSAEs (50\% versus $44 \%$ ), osteoporosis, and fractures. Of note, the observation of increase in fractures with AIs has been made in trials which started over two decades ago, before bone health awareness, BMD testing, and bone agents (that is, bisphosphonates) were available. In the more contemporary MAP. 3 breast cancer prevention trial comparing exemestane versus placebo, the absence of excess fragility fractures and total fractures and the $\geq 10 \%$ decreases in areal $\mathrm{BMD}$ in the exemestane group were reassuring $[25,72]$. Of note, similar baseline BMD in the two groups and the use of bisphosphonate therapy both before and during the study were reported in this study.

Several professional medical societies and organizations have published guidelines for the use of bisphosphonates in preventing and treating bone loss during AIs [21,22,73-75]. Therefore, the simple adherence to implemented standard medical practice (for example, bone health monitoring and vitamin $\mathrm{D}$ and calcium supplementation when appropriate) should largely obviate the fracture risk associated with AI use. Moreover, although AIs increase the rate of bone turnover and decrease bone density in post-menopausal women [76,77], these effects seem to diminish after completing AI therapy $[78,79]$.

Regarding compliance, Cuzick and colleagues [80], in contrast with other investigators, noted better treatment adherence in patients experiencing vasomotor symptoms and joint symptoms. Toxicity may depend on the kind of patient reporting these symptoms and may be related to treatment compliance, which would explain improved treatment outcomes in these patients [81].

Interestingly, in 9,325 patients enrolled in the TEAM trial [82], patients with specific AEs - including vasomotor symptoms, MSAEs, and vulvo-vaginal symptoms - had significantly better DFS and OS at multivariate analysis and fewer distant metastases than patients reporting nonspecific or no AEs (Table 4). Increasing numbers of specific AEs were also significantly associated with better survival outcomes. Similarly, a recent retrospective analysis of the BIG 1-98 trial suggests that the occurrence of arthralgia/myalgia/carpal tunnel symptoms at 3 and 12 months is associated with a significantly better DFS and BC-free interval irrespective of treatment (letrozole or tamoxifen) [83]. Certain specific AEs may be valuable predictors and biomarkers of treatment efficacy, although further prospective investigation is warranted.

\section{Cognitive function with aromatase inhibitors}

While many patients report 'chemotherapy fog' manifesting as a decrease in short-term memory during chemotherapy [84], less is known about the potential 
Table 3 Incidence of treatment-related serious adverse events in the main adjuvant aromatase inhibitor trials [71]

\begin{tabular}{|c|c|c|c|c|c|}
\hline Study & $\begin{array}{c}\text { Arms number }{ }^{\mathrm{a}} \text { MSK: } \% \\
\text { (comparative }^{\left(\text {value }^{\mathrm{b}}\right.}\end{array}$ & $\begin{array}{c}\text { Arms number }{ }^{\mathrm{a}} \text { BMD } \\
\text { (T-score): \% (comparative } \\
P \text { value })^{\mathrm{b}}\end{array}$ & $\begin{array}{l}\text { Arms number }{ }^{\mathrm{a}} \mathrm{CV} \text { events: } \% \\
\quad \text { (comparative } P \text { value) }\end{array}$ & $\begin{array}{c}\text { Arms number }{ }^{\mathrm{a}} \text { Gynae: } \\
\text { \% (comparative } \\
P \text { value) }\end{array}$ & $\begin{array}{c}\text { Arms number }{ }^{\mathrm{a}} \text { Hot } \\
\text { flashes : } \% \\
\text { (comparative } P \text { value) }\end{array}$ \\
\hline \multirow[t]{8}{*}{ ATAC } & A versus $T 6,241$ & A versus T (5 years) 197 & A versus T 6,186 & $\begin{array}{c}\text { A versus T (5 years) } \\
6,186\end{array}$ & A versus $T$ (5 years) 6,186 \\
\hline & \multirow[t]{2}{*}{$\begin{array}{l}\text { Arthralgia: } 35.6 \text { versus } \\
29.4(<0.0001)\end{array}$} & \multirow[t]{2}{*}{$\begin{array}{l}\text { LS: }-6.1 \text { versus }+2.8 \\
(<0.0001)\end{array}$} & $\begin{array}{c}\text { Ischemic CV event: } 4.1 \text { versus } \\
3.4(0.1)\end{array}$ & $\begin{array}{l}\text { Gynecologic event }{ }^{\mathrm{d}}: 3.0 \\
\text { versus } 10.0(<0.0001)\end{array}$ & \multirow[t]{7}{*}{35.7 versus $40.9(<0.0001)$} \\
\hline & & & $\begin{array}{c}\text { Ischemic CerebroV event: } 2.0 \\
\text { versus } 2.8(0.03)\end{array}$ & $\begin{array}{l}\text { Vaginal bleeding. } 5.4 \\
\text { versus } 10.2(<0.0001)\end{array}$ & \\
\hline & \multirow[t]{5}{*}{$\begin{array}{c}\text { CTS: } 3.0 \text { versus } 1.0 \\
(<0.0001)\end{array}$} & \multirow[t]{5}{*}{$\begin{array}{l}\text { Hip: }-7.2 \text { versus }+0.7 \\
(<0.0001)\end{array}$} & $\begin{array}{l}\text { Venous TE event: } 2.8 \text { versus } 4.5 \\
(0.0004)\end{array}$ & $\begin{array}{l}\text { Vaginal discharge: } 3.5 \\
\text { versus } 13.2(<0.0001)\end{array}$ & \\
\hline & & & DVT event: 1.6 versus $2.4(0.02)$ & \multirow{4}{*}{$\begin{array}{l}\text { Reduced libido: } 1.0 \\
\text { versus } 0.4(<0.0001)\end{array}$} & \\
\hline & & & CV death`: 2.0 versus 2.0 (NR) & & \\
\hline & & & $\begin{array}{c}\text { CerebroV death`: } 0.8 \text { versus } 0.9 \\
\text { (NR) }\end{array}$ & & \\
\hline & & & $\begin{array}{c}\text { Hypercholesterolemia: } 9.0 \\
\text { versus } 3.0(<0.0001)\end{array}$ & & \\
\hline \multirow[t]{5}{*}{$\begin{array}{l}\mathrm{BIG} \mathrm{1-} \\
98\end{array}$} & $L$ versus T 8,028 $(4,992)^{a}$ & \multirow[t]{5}{*}{ NA } & $L$ versus T 4,895 & $\begin{array}{c}\mathrm{L} \text { versus T (6 years) } \\
3,074\end{array}$ & $L$ versus $T$ ( 6 years) 3,074 \\
\hline & $\begin{array}{c}\text { Arthralgia: } 20.0 \text { versus } \\
13.5(<0.001)\end{array}$ & & $\begin{array}{c}\text { Cardiac event: } 5.5 \text { versus } 5.0 \\
(0.48)\end{array}$ & $\begin{array}{l}\text { Vaginal bleeding: } 5.1 \\
\text { versus } 9.9(<0.001)\end{array}$ & 37.7 versus 42.9 (NR) \\
\hline & \multirow[t]{3}{*}{$\begin{array}{l}\text { Myalgia: } 7.1 \text { versus } 6.1 \\
(0.19)\end{array}$} & & $\begin{array}{c}\text { CerebroV accident or TIA: } 1.4 \\
\text { versus } 1.4(0.90)\end{array}$ & \multirow[t]{3}{*}{$\begin{array}{l}\text { Night sweating: } 15.6 \\
\text { versus } 19.4 \text { (NR) }\end{array}$} & \\
\hline & & & TE event: 2.0 versus $3.8(<0.001)$ & & \\
\hline & & & $\begin{array}{l}\text { Hypercholesterolemia: } 50.6 \\
\text { versus } 24.6(<0.001)\end{array}$ & & \\
\hline \multirow[t]{5}{*}{ TEAM } & E versus T 9,779 & E versus T (1 year) 161 & E versus T 9,779 & $\begin{array}{c}\text { E versus T ( } 2.75 \text { years }) \\
9,779\end{array}$ & NA \\
\hline & \multirow[t]{4}{*}{$\begin{array}{l}\text { Arthralgia: } 17.9 \text { versus } \\
\quad 9.2(\leq 0.001)\end{array}$} & $\begin{array}{c}\text { LS: }-2.8 \text { versus }+0.5 \\
(0.0008)\end{array}$ & $\begin{array}{c}\text { Ischemic CV event/Ml: } 0.8 \\
\text { versus } 0.7 \text { (NR) }\end{array}$ & $\begin{array}{l}\text { Endometrial } \\
\text { hyperplasia: } 0.0 \text { versus } \\
2.0(<0.0001)\end{array}$ & \\
\hline & & Hip: -2.2 versus $+0.4(0.04)$ & & $\begin{array}{l}\text { Vaginal hemorrhage: } \\
1.6 \text { versus } 3.1(<0.0001)\end{array}$ & \\
\hline & & & & $\begin{array}{l}\text { Vaginal discharge: } 2.3 \\
\text { versus } 6.8(<0.0001)\end{array}$ & \\
\hline & & $\mathrm{FN}:+0.3$ versus $-1.8(0.414)$ & & $\begin{array}{l}\text { Vaginal infection: } 0.7 \\
\text { versus } 2.2(<0.0001)\end{array}$ & \\
\hline \multirow[t]{4}{*}{ MA.17 } & L versus placebo 5,187 & L versus placebo 226 & $\mathrm{~L}$ versus placebo 5,187 & $\begin{array}{l}\mathrm{L} \text { versus placebo }(2.5 \\
\text { years) } 5,187\end{array}$ & L versus placebo 5,187 \\
\hline & $\begin{array}{l}\text { Arthralgia: } 25.0 \text { versus } \\
\qquad 21.0(<0.001)\end{array}$ & LS: -5.4 versus $-0.7(0.008)$ & CV disease: 5.8 versus $5.6(0.76)$ & $\begin{array}{l}\text { Vaginal bleeding: } 6 \\
\text { versus } 8 \text { (0.005) }\end{array}$ & 58 versus 54 (0.003) \\
\hline & $\begin{array}{l}\text { Arthritis: } 6.0 \text { versus } 5.0 \\
(0.07)\end{array}$ & $\begin{array}{c}\text { Hip: }-3.6 \text { versus }-0.7 \\
(0.044)\end{array}$ & $\begin{array}{c}\text { MI: } 0.3 \text { versus } 0.4 \text { (NR) Stroke/ } \\
\text { TIA: } 0.7 \text { versus } 0.6 \text { (NR) }\end{array}$ & $\begin{array}{l}\text { Vaginal dryness: } 6 \\
\text { versus } 5(0.26)\end{array}$ & \\
\hline & $\begin{array}{c}\text { Myalgia: } 15.0 \text { versus } 12.0 \\
(0.0041)\end{array}$ & & $\begin{array}{c}\text { TE event: } 0.4 \text { versus } 0.2 \text { (NR) } \\
\text { Hypercholesterolemia: } 16 \text { versus } \\
16(0.79)\end{array}$ & & \\
\hline
\end{tabular}

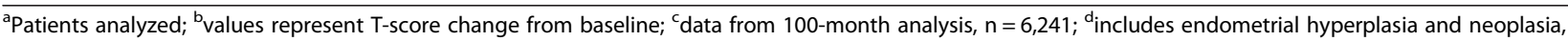
cervical neoplasm, and enlarged uterine fibroids. A, anastrozole; ATAC, Arimidex, Tamoxifen, Alone or in Combination; BIG, Breast International Group; BMD, bone mineral density; CerebroV, cerebrovascular; CTS, carpal tunnel syndrome; CV, cardiovascular; DVT, deep vein thromboembolic; E, exemestane; FN, femoral neck; L, letrozole; LS, lumbar spine; MI, myocardial infarction; MSK, musculoskeletal; NA, not available; NR, not reported; T, tamoxifen; TE, thromboembolic; TEAM, Tamoxifen Exemestane Adjuvant Multinational; TIA, transient ischemic attack.

effects of endocrine therapy on cognitive function [71]. Breast Cancer Action conducted an online survey in 1,199 women on AIs and found that approximately $2 \%$ of the respondents experienced cognitive impairment and that nearly half (48\%) reported 'mental fuzziness' which led only $3 \%$ to stop taking their AI [85]. Few of the large AI trials reported on cognitive function during treatment, so available data are limited. 
Table 4 Outcomes in relation to specific adverse events in the Tamoxifen Exemestane Adjuvant Multinational (TEAM) trial [82]

\begin{tabular}{|c|c|c|c|c|c|}
\hline Outcome measure & $\mathrm{AE}$ & Number of AEs (yes versus no AE) & Hazard ratio & $95 \% \mathrm{Cl}$ & $P$ value \\
\hline \multirow[t]{4}{*}{ DFS } & VMS & 249 versus 837 & 0.731 & $0.618-0.866$ & $<0.001$ \\
\hline & MSAE & 239 versus 847 & 0.826 & $0.694-0.982$ & 0.030 \\
\hline & WS & 89 versus 997 & 0.769 & $0.585-1.01$ & 0.058 \\
\hline & Overall & 418 versus 668 & 0.735 & $0.632-0.855$ & $<0.001$ \\
\hline \multirow[t]{4}{*}{ OS } & VMS & 147 versus 617 & 0.583 & $0.424-0.803$ & 0.001 \\
\hline & MSAE & 151 versus 613 & 0.811 & $0.654-1.005$ & 0.055 \\
\hline & WS & 51 versus 713 & 0.570 & $0.391-0.831$ & 0.003 \\
\hline & Overall & 268 versus 496 & 0.680 & $0.565-0.819$ & $<0.001$ \\
\hline \multirow[t]{4}{*}{$\overline{\mathrm{DM}}$} & VMS & 165 versus 490 & 0.813 & $0.664-0.996$ & 0.046 \\
\hline & MSAE & 138 versus 517 & 0.749 & $0.601-0.934$ & 0.010 \\
\hline & WS & 54 versus 601 & 0.687 & $0.435-1.085$ & 0.107 \\
\hline & Overall & 261 versus 394 & 0.783 & $0.651-0.942$ & 0.010 \\
\hline
\end{tabular}

$\overline{A E}$, adverse event; $C l$, confidence interval; DFS, disease-free survival; DM, distant metastases; MSAE, musculoskeletal adverse event; OS, overall survival; VMS, vasomotor symptoms; VVS, vulvovaginal symptoms.

In the ATAC trial, impairments in processing speed and verbal memory were reported in women on anastrozole as compared with healthy women [86]. A crosssectional study in 31 post-menopausal women with early $\mathrm{BC}$ on anastrozole or tamoxifen for a minimum of 3 months [87] found significantly poorer verbal and visual learning and memory in the anastrozole versus tamoxifen group. These findings must be interpreted with caution because of the small sample size and use of a crosssectional design.

A prospective analysis from BIG 1-98 showed that cognitive function was significantly better among patients on letrozole versus tamoxifen at the end of the 5year treatment period [88]. A second analysis comparing the 5-year assessments with those collected about 1 year later showed a significant improvement in cognitive function of similar magnitude following completion of endocrine therapy in both groups [89].

A neuropsychological cross-sectional study from the TEAM trial evaluated the cognitive functioning during the first year's treatment [90]. In the exemestane group $(n=62), 24 \%$ of patients reported reduced daily memory functioning compared with $6 \%$ of healthy controls, but there was no statistically significant difference between the two groups in any cognitive domain after 1 year of treatment [91]. Thus, the evidence of the effects of adjuvant endocrine therapy on cognitive function is limited and inconclusive, and further studies are required.

\section{Predictive factors of benefit from an aromatase inhibitor}

As might be predicted, patients at highest risk based on the number of involved nodes, tumor grade, size, vascular invasion, and Ki67 gained most from an AI compared with tamoxifen [64,92,93], and a recent subset analysis of BIG 1-98 data also showed a more pronounced benefit of letrozole in invasive lobular versus invasive ductal carcinoma [94].

There is evidence from neoadjuvant studies suggesting that $\mathrm{ER}^{+} \mathrm{HER}^{+}$(human epidermal growth factor receptor) patients might respond better to AIs than to tamoxifen [95-97]. However, although data from the TEAM trial suggested a significant treatment-by-marker effect between $\mathrm{AI} /$ tamoxifen treatment and HER1, 2, and 3 expression in the 2.75 years prior to switching patients initially treated with tamoxifen to exemestane [98], this was not observed in the ATAC and BIG 1-98 trials. In these two trials, the HER2 status did not predict for benefit from an AI versus tamoxifen and patients with HER2-overexpressing or -amplified tumors were found to have a worse prognosis than HER2 $2^{-}$patients, regardless of whether they received tamoxifen or an AI $[99,100]$. Hence, the HER2 status is not considered a selection criterion for the most appropriate endocrine treatment.

\section{Extended adjuvant endocrine therapy}

Women with $\mathrm{HR}^{+}$early $\mathrm{BC}$ are at continuous risk of relapse up to 15 years after diagnosis, despite being on adjuvant endocrine therapy for around 5 years [13,101]. Several trials have addressed whether extended adjuvant endocrine therapy beyond 5 years reduces the risk of late recurrence.

\section{NCIC CTG MA.17/BIG 1-97}

NCIC CTG MA.17/BIG 1-97 tested the effectiveness of 5 years of letrozole after completion of the standard 4 to 6 years of adjuvant tamoxifen and was the first phase III trial to demonstrate an OS advantage with an adjuvant AI [50]. 
At a median follow-up of 2.4 years, a highly significant reduction in the risk of recurrence was seen with letrozole versus placebo (DFS hazard $=0.57, P=0.00008$ ) [50]. Based on this, the safety monitoring committee recommended study unblinding, allowing patients in the control group to switch to letrozole (see below). At a median follow-up of 30 months, a relative reduction in recurrence risk of $42 \%$ occurred with letrozole [63]. Letrozole treatment significantly reduced the risk of distant metastases in both nodenegative and -positive patients $(P=0.002)$ and significantly improved OS by $39 \%$ in node-positive patients compared with placebo (hazard ratio $=0.61, P=0.04$ ). A further ITT analysis of all outcomes, before and after unblinding, was performed at a median follow-up of 64 months (Table 3). Although $66 \%$ of women originally on placebo crossed over to letrozole, a $32 \%$ reduction in the hazard for a DFS event persisted for women originally randomly assigned to receive letrozole [102]. More recently, Jin and colleagues [56] conducted an analysis through an IPCW Cox model to adjust for the effects of treatment crossover, demonstrating at a median follow-up of 64 months that patients initially randomly assigned to receive letrozole had hazard ratios of 0.52, 0.51, and 0.61 for DFS, distant DFS (DDFS), and OS, respectively (all $P<0.0001$ ).

Exploratory and subgroup analyses of MA.17 showed that letrozole had similar benefits in older $(>70$ years, $n=$ $1,323,26 \%)$ versus younger (<60 years) patients without any increase in toxicity compared with placebo. Women who were pre-menopausal at diagnosis but who became post-menopausal during the initial 5 years $(n=889)$ experienced significantly greater benefit on letrozole (hazard ratio for DFS $=0.25$ ) than older/post-menopausal women $(\mathrm{n}=4,277)$ (hazard ratio $=0.69, P=0.02$ for interaction) [103]. Therefore, pre-menopausal BC patients who have become menopausal by the end of adjuvant tamoxifen also benefit significantly from extended adjuvant therapy.

The optimal duration of extended adjuvant endocrine therapy remains unclear. An exploratory analysis conducted by Ingle and colleagues [104] suggested that the hazard ratio continues to fall for DFS and DDFS but not for OS out to 48 months, indicating that the benefit of letrozole increases with longer exposure.

The $66 \%$ crossover rate in MA.17 from placebo to letrozole after unblinding offered a good opportunity to test whether delayed initiation of an AI could still be of any benefit [105]. At the time of trial unblinding, 1,579 women initially on placebo elected to receive letrozole and 804 women chose no further treatment. At a median follow-up of 5.3 years, a significant reduction in recurrence risk (adjusted hazard ratio $=0.37, P<0.0001)$ and a significant $61 \%$ improvement in DDFS were found in patients who switched to letrozole, although they had more adverse prognostic factors. These results suggest that therapy given more than 7 years after diagnosis can change the chronic relapsing behavior of $\mathrm{HR}^{+} \mathrm{BC}$. They also show that delayed letrozole commencement after stopping tamoxifen can still be of benefit.

\section{Other extended adjuvant therapy trials with aromatase inhibitors}

Other trials have been conducted to investigate the role of extended adjuvant AI therapy (Table 1). In the ABCSG Trial $6 \mathrm{a}, \mathrm{HR}^{+}$post-menopausal patients who were disease-free after 5 years of adjuvant tamoxifen (with or without AG) were randomly assigned to 3 years of anastrozole or no further treatment [51]. With 856 patients and a median follow-up of 62.3 months, anastrozole further reduced the risk of a $\mathrm{BC}$ event (locoregional recurrence, distant recurrence, or contralateral $\mathrm{BC}$ ) by $38 \%$ versus no further treatment (hazard ratio = $0.62, P=0.031$ ). There was no statistically significant difference in OS between the two arms.

NSABP-B33 investigated extended adjuvant therapy with exemestane in post-menopausal women with clinical T1-3N1M0 BC who were disease-free after 5 years of adjuvant tamoxifen [52]. This trial closed prematurely after the publication of the results of MA.17. At 30 months of median follow-up, ITT analysis showed a trend of improvement in 4-year DFS (91\% versus 89\%; relative risk $0.68 ; P=0.07$ ) and a statistically significant improvement in 4-year recurrence-free survival $(96 \%$ versus $94 \%$; $R R=0.44 ; P=0.004)$.

The Adjuvant post-Tamoxifen Exemestane versus Nothing Applied trial compared exemestane versus observation after 5 years of previous tamoxifen [106]. This trial was prematurely closed after recruiting only 448 patients.

The data sets from these trials have been analyzed in an EBCTG meta-analysis [107]. At a median follow-up of 2.5 years, extended adjuvant AI treatment was associated with an absolute $2.9 \%$ decrease in $\mathrm{BC}$ recurrence (relative decrease of $43 \%, P<0.00001$ ) and an absolute $0.5 \%$ decrease in $\mathrm{BC}$ mortality (relative decrease of $27 \%$, $P=0.11$ ). Of note, the authors emphasized that the magnitude of the effects seen on DFS and OS in these analyses is likely underestimated because of some crossover after unblinding.

\section{Ongoing studies}

Several ongoing studies are investigating extended AIs in regard to optimal duration, intermittent versus continuous use, and benefit after AIs used during the first 5 years of therapy (Table 5) [108].

\section{Tamoxifen beyond 5 years}

Results of relatively small trials assessing tamoxifen treatment for more than 5 years were inconclusive until recently [109-112]. The large Adjuvant Tamoxifen: 
Table 5 Ongoing clinical trials of extended aromatase inhibitor therapy

\begin{tabular}{|c|c|c|c|c|}
\hline Study & Number & Population (treatment received pre-enrollment) & Arms at random assignment & Study number \\
\hline \multirow[t]{2}{*}{ MA.17R } & 1,918 & Prior 4.5-6 years of $\mathrm{Al}$, with or without prior $\mathrm{T}^{\mathrm{a}}$ & $\mathrm{L}$ (5 years) versus placebo (5 years) & NCT00754845 \\
\hline & & Completed $\mathrm{Al} \leq 2$ years prior random assignment & & \\
\hline SALSA & 3,486 & Any endocrine therapy (5 years) & A (5 years) versus A ( 2 years) & NCT00295620 \\
\hline LEAD & 4,050 & $\mathrm{~T}(4-6$ years $)$ & $L$ (5 years) versus L (2-3 years) & NCT01064635 \\
\hline DATA & 1,900 & $\top(2-3$ years $)$ & A (6 years) versus A (3 years) & NCT00301457 \\
\hline NSABP-B42 & 3,966 & $\mathrm{Al}$ or $\mathrm{T} \rightarrow \mathrm{Al}^{\mathrm{b}}$ (to 5 years) & L (5 years) versus placebo (5 years) & NCT00382070 \\
\hline SOLE & 4,800 & Any endocrine therapy ${ }^{\complement}$ ( 5 years) & $L$ (5 years) versus intermittent ${ }^{d} L$ (5 years) & NCT00553410 \\
\hline
\end{tabular}

${ }^{a}$ Including as part of MA.17. ${ }^{\mathrm{b}}$ Tamoxifen must have been up to 3 years and may not have been given during years 4 and 5 of the 5 years of adjuvant hormonal therapy. 'Must have completed 4 to 6 years of prior selective estrogen receptor modulators or aromatase inhibitors (Als), or a sequential combination of both. When calculating 4 to 6 years, neoadjuvant endocrine therapy should not be included. ${ }^{\mathrm{d}}$ Intermittent: 48 months over 5 years: $4 \times 9$ months ( 9 months followed by 3 -month treatment-free interval in years 1 to 4 , at least 36 months) plus $1 \times 12$ months in years 5 at least 48 months. $\rightarrow$, switch to; A, anastrozole; DATA, Different Durations of Anastrozole after Tamoxifen trial; L, letrozole; LEAD, Letrozole Adjuvant Therapy Duration trial; NSABP, National Surgical Adjuvant Breast and Bowel Project; SALSA, Secondary Adjuvant Long-term Study with Arimidex trial; SOLE, Study of Letrozole Extension trial; T, tamoxifen.

Longer Against Shorter (ATLAS) trial addressed this uncertainty, and results on 6,846 women with $\mathrm{ER}^{+}$disease randomly assigned to continue tamoxifen treatment to 10 years or not (control group) showed that 10 years of tamoxifen further reduced the risk of relapse $(P=0.002)$, BC mortality $(P=0.01)$, and all-cause mortality $(P=$ $0.01)$ compared with 5 years [113]. Most of this benefit seemed to accrue late, and there were only modest reductions in recurrence rates during the 5 extra years of tamoxifen and a more impressive carryover benefit during the 5 years of follow-up after completion of 10 years of tamoxifen (Table 6). Furthermore, reduced mortality was apparent only after completion of 10 years of tamoxifen. Thus, the benefit of continuing tamoxifen for a further 5 years is the sum of the carryover benefit from the first 5 years and the sequential benefit of a further 5 years, giving a total estimated relapse risk reduction of $39 \%(P<0.0001)$ and risk reduction of BC mortality of $36 \%(P<0.0001)$. After completion of 10 years of tamoxifen, this estimated risk was reduced by $30 \%$ for relapse $(2 P=0.01)$ and $48 \%$ for mortality $(2 P<0.0001)$, continuing for at least 5 years. These carryover benefits contribute substantially to the cumulative benefits of treatment, particularly because toxic effects occur mostly during the active treatment period. The most important AEs were an increased risk of endometrial cancer $(R R=1.74)$ and PE (1.87) after 10 years of treatment. Reassuringly, no increase was noted in stroke incidence, and a decrease in incidence of ischemic heart disease was noted (0.76). Overall the benefits of extended tamoxifen seemed to substantially outweigh the risks.

\section{Table 6 Clinical trials testing tamoxifen beyond 5 years}

\begin{tabular}{|c|c|c|c|c|c|}
\hline Study & Number & Population & Arms & $\begin{array}{l}\text { Disease-free survival } \\
\text { hazard ratio }(95 \% \mathrm{Cl})\end{array}$ & $\begin{array}{c}\text { Overall survival } \\
\text { hazard ratio }(95 \% \mathrm{CI})\end{array}$ \\
\hline \multirow[t]{2}{*}{$\begin{array}{l}\text { ATLAS } \\
\text { [113] } \\
\text { Open- } \\
\text { label }\end{array}$} & \multirow[t]{2}{*}{$6,846^{a}$} & \multirow[t]{2}{*}{$\begin{array}{c}\text { Pre- and post-menopausal women with } \\
\mathrm{ER}^{+} \mathrm{EBC} \text { who already received T for } \\
5 \text { years (in the context of ATLAS } \\
\text { trial total number }=12,894 \text { ) }\end{array}$} & \multirow[t]{2}{*}{$\begin{array}{l}\text { T for additional } \\
5 \text { years ( } 10 \\
\text { years) versus } \\
\text { stop T (5 years) }\end{array}$} & \multirow{2}{*}{ 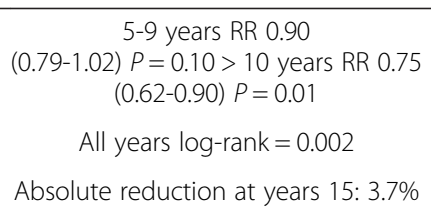 } & \multirow[t]{2}{*}{$\begin{array}{c}\text { BC mortality: } 5-9 \text { years RR } \\
0.97(0.79-1.18) P=0.74 \mathrm{BC} \\
\text { mortality: }>10 \text { years RR } 0.71 \\
(0.58-0.88) P=0.002\end{array}$} \\
\hline & & & & & \\
\hline \multirow{2}{*}{$\begin{array}{l}\text { aTToM } \\
{[114]^{b}} \\
\text { Open- } \\
\text { label }\end{array}$} & \multirow[t]{2}{*}{6,953} & \multirow{2}{*}{$\begin{array}{c}\text { Invasive EBC who had already been } \\
\text { taking T for } 5 \text { years. 2,755 ER }{ }^{+} \text {(39\%) and } \\
\text { 4,198 ER untested (61\%) (estimated } 80 \% \\
\text { ER }^{+} \text {if status unknown) }\end{array}$} & \multirow{2}{*}{$\begin{array}{l}\text { T for additional } \\
5 \text { years versus } \\
\text { no further } \\
\text { treatment }\end{array}$} & RR $0.85(0.76-0.95) P=0.003$ & $\begin{array}{c}\text { BC mortality: } 5-9 \text { years RR } \\
1.08(0.85-1.38)\end{array}$ \\
\hline & & & & Absolute reduction 4\% & $\begin{array}{c}\text { BC mortality: }>10 \text { years RR } \\
0.75 \text { (0.63-0.90) } P=0.007 \mathrm{BC} \\
\text { mortality: all years RR } 0.88 \\
(0.74-1.03) P=0.1\end{array}$ \\
\hline \multirow{2}{*}{$\begin{array}{l}\text { Pooled } \\
\text { analysis } \\
\text { ATLAS + } \\
\text { aTToM } \\
{[114]^{b}}\end{array}$} & \multirow[t]{2}{*}{17,477} & \multirow[t]{2}{*}{$\begin{array}{l}10,543^{c} \mathrm{ER}^{+} \text {from ATLAS plus 6,934 ER }{ }^{+} \\
\text {from aTTom }\end{array}$} & \multirow[t]{2}{*}{$\begin{array}{l}\text { T } 10 \text { versus } 5 \\
\text { years }\end{array}$} & \multirow[t]{2}{*}{ NA } & $\begin{array}{c}\text { BC mortality: } 5-9 \text { years } R R \\
0.97(0.84-1.15)\end{array}$ \\
\hline & & & & & $\begin{array}{l}\text { BC mortality: }>10 \text { years RR } \\
0.75(0.65-0.86) P=0.00004\end{array}$ \\
\hline
\end{tabular}

\footnotetext{
${ }^{a}$ Analysis of estrogen receptor-positive $\left(\mathrm{ER}^{+}\right)$patients only; ${ }^{\mathrm{b}}$ figures are derived from the abstract [114] and the presentation at American Society of Clinical Oncology meeting 2013 available online; ' IPCW (inverse probability of censoring weighted) estimate of the effect in ER ${ }^{+}$. ATLAS, Adjuvant Tamoxifen: Longer Against Shorter; aTToM, Adjuvant Tamoxifen-To Offer More?; BC, breast cancer; Cl, confidence interval; EBC, early breast cancer; RR, rate ratio; T, tamoxifen.
} 
Likewise, the Adjuvant Tamoxifen-To Offer More? (aTTom) trial randomly assigned 6,953 UK women in remission after 5 years of tamoxifen to 5 more years of tamoxifen or to stop (Table 6) [114]. The compliance rate was $75 \%$ in the 10 -year tamoxifen study arm. The BC recurrence rates were $16.7 \%$ in the 10 -year study group and $19.3 \%$ in the 5-year study group. Similarly to the ATLAS trial, there was a time-dependent reduced risk of recurrence with 10 years of tamoxifen with RRs of 0.99 during years 5 to $6,0.84$ during years 7 to 9 , and 0.75 subsequently. Longer treatment also reduced BC mortality in a timedependent fashion with RRs of 1.03 during years 5 to 9 and 0.77 later and overall mortality RRs of 1.05 during years 5 to 9 and 0.86 later. Non-BC mortality was little affected (457 versus 467 deaths; $R R=0.94$ ). The most serious $A E$ of long-term tamoxifen was an increase in endometrial cancer risk: there were 102 versus 45 endometrial cancers $(\mathrm{RR}=$ 2.20, $P<0.0001)$ with $37(1.1 \%)$ versus $20(0.6 \%)$ deaths (absolute hazard $0.5 \%, P=0.02)$. The pooled analysis of the UK aTTom and the international ATLAS trials showed enhanced significance of recurrence $(P<0.0001), \mathrm{BC}$ mortality $(P=0.002)$, and OS $(P=0.005)$ benefits [114].

In conclusion, in $\mathrm{ER}^{+}$disease, continuing tamoxifen to year 10 rather than just to year 5 produces further reductions in recurrence, from year 7 onward, and BC mortality after year 10. Taken together with the reduction in BC deaths seen in trials of 5 years of tamoxifen versus none, these results indicate that adjuvant tamoxifen for 10 years, compared with no tamoxifen, reduces BC mortality by about one third in the first 10 years after diagnosis and by half subsequently. No significant heterogeneity was observed in the proportional risk reduction with respect to patient or tumor characteristics or site of first relapse.

The important questions of which patients really benefit and whether extended adjuvant endocrine therapy should be with tamoxifen or an AI in post-menopausal women currently remain unanswered. Active research is currently ongoing on molecular features and gene expression scores combined with standard clinico-pathological criteria to tailor extended endocrine therapy [115].

\section{Conclusions}

Adjuvant endocrine therapy significantly reduces the risk of recurrence and death in women with early $\mathrm{HR}^{+} \mathrm{BC}$. In pre-menopausal women, tamoxifen and $\mathrm{OvS}$ are of similar benefit. Currently there is no strong evidence that combined treatment is better than either alone, but results of two major trials addressing the value of additional OvS are awaited. In post-menopausal women, AIs are significantly more effective than tamoxifen in preventing recurrence but so far only letrozole has been shown to have survival benefit. For women at only low or moderate risk, there is little difference in efficacy between the two treatments.
Extended adjuvant endocrine therapy with an AI (post-menopausal) or tamoxifen beyond an initial 5 years of tamoxifen further reduces the risk of relapse. The relative merits of these two approaches and the selection of patients requiring long-term endocrine therapy are now important questions requiring further research, as is the important issue of the optimum duration of an AI if started upfront rather than after tamoxifen.

\section{Abbreviations}

ABCSG: Austrian breast and colorectal cancer study group; AE: Adverse event; AG: Aminoglutethimide; Al: Aromatase inhibitor; ATAC: Arimidex, tamoxifen, alone or in combination; ATLAS: Adjuvant tamoxifen: longer against shorter; aTTom: Adjuvant tamoxifen-to offer more?; BC: Breast cancer; BIG: Breast international group; BMD: Bone mineral density; CYP2D6: Cytochrome P450 2D6; DDFS: Distant disease-free survival: DFS: Disease-free survival; EBCTCG: Early breast cancer trialists' collaborative group; ER: Estrogen receptor; HER: Human epidermal growth factor receptor; HR: Hormone receptor; IES: Intergroup exemestane study; IPCW: Inverse probability of censoring weighted; ITT: Intention to treat; LHRH: Luteinizing hormonereleasing hormone; MSAE: Musculoskeletal adverse event; NSABP: National surgical adjuvant breast and bowel project; OS: Overall survival; OvA: Ovarian ablation; OvS: Ovarian suppression; PE: Pulmonary embolus;

PgR: Progesterone receptor; RR: Rate ratio; SAE: Serious adverse effect; SOFT: Suppression of ovarian function trial; TEAM: Tamoxifen exemestane adjuvant multinational; TEXT: Tamoxifen and exemestane trial; TTDR: Time to distant recurrence; TTR: Time to recurrence.

\section{Competing interests}

The authors declare that they have no competing interests.

\section{Acknowledgments}

We would like to thank the Cridlan Fund for supporting GS.

\section{Published: 01 Apr 2014}

\section{References}

1. Harvey JM, Clark GM, Osborne CK, Allred DC: Estrogen receptor status by immunohistochemistry is superior to the ligand-binding assay for predicting response to adjuvant endocrine therapy in breast cancer. J Clin Oncol 1999, 17:1474-1481.

2. Nunn T: On Cancer of the Breast. London, UK: J. \& A. Churchill; 1882.

3. Love RR, Philips J: Oophorectomy for breast cancer: history revisited. J Natl Cancer Inst 2002, 94:1433-1434

4. Early Breast Cancer Trialists' Collaborative Group: Ovarian ablation in early breast cancer: overview of the randomised trials. Lancet 1996, 348:1189-1196.

5. Early Breast Cancer Trialists' Collaborative Group: Tamoxifen for early breast cancer: an overview of the randomised trials. Lancet 1998, 351:1451-1467.

6. Early Breast Cancer Trialists' Collaborative Group: Polychemotherapy for early breast cancer: an overview of the randomised trials. Lancet 1998 352:930-942.

7. Controlled trial of tamoxifen as adjuvant agent in management of early breast cancer. Interim analysis at four years by nolvadex adjuvant trial organisation. Lancet 1983, 1:257-261.

8. Controlled trial of tamoxifen as a single adjuvant agent in the management of early breast cancer. 'Nolvadex' Adjuvant trial organisation. Br J Cancer 1988, 57:608-611.

9. Cyclophosphamide and tamoxifen as adjuvant therapies in the management of breast cancer. CRC adjuvant breast trial working party. Br J Cancer 1988, 57:604-607.

10. Fisher B, Costantino J, Redmond C, Poisson R, Bowman D, Couture J, Dimitrov NV, Wolmark N, Wickerham DL, Fisher ER, Margolese R, Robidoux A, Shibata H, Terz J, Paterson AHG, Feldman MI, Farrar W, Evans J, Lickley HL, Ketner M: A randomized clinical trial evaluating tamoxifen in the treatment of patients with node-negative breast cancer who have estrogen-receptor-positive tumors. N Engl J Med 1989, 320:479-484.

11. Fisher B, Jeong JH, Bryant J, Anderson S, Dignam J, Fisher ER, Wolmark N: Treatment of lymph-node-negative, oestrogen-receptor-positive breast 
cancer: long-term findings from national surgical adjuvant breast and bowel project randomised clinical trials. Lancet 2004, 364:858-868.

12. Early Breast Cancer Trialists' Collaborative Group: Effects of adjuvant tamoxifen and of cytotoxic therapy on mortality in early breast cancer. An overview of 61 randomized trials among 28,896 women. N Engl J Med 1988, 319:1681-1692

13. Early Breast Cancer Trialists' Collaborative Group (EBCTCG): Effects of chemotherapy and hormonal therapy for early breast cancer on recurrence and 15-year survival: an overview of the randomised trials. Lancet 2005, 365:1687-1717.

14. Early Breast Cancer Trialists' Collaborative Group (EBCTCG), Davies C, Godwin J, Gray R, Clarke M, Cutter D, Darby S, McGale P, Pan HC, Taylor C, Wang YC, Dowsett $M$, Ingle J, Peto R: Relevance of breast cancer hormone receptors and other factors to the efficacy of adjuvant tamoxifen: patient-level meta-analysis of randomised trials. Lancet 2011, 378:771-784.

15. Hammond ME, Hayes DF, Dowsett M, Allred DC, Hagerty KL, Badve S, Fitzgibbons PL, Francis G, Goldstein NS, Hayes M, Hicks DG, Lester S, Love R, Mangu PB, McShane L, Miller K, Osborne CK, Paik S, Perlmutter J, Rhodes A, Sasano H, Schwartz JN, Sweep FC, Taube S, Torlakovic EE, Valenstein P, Viale G, Visscher D, Wheeler T, Williams RB, et al: American society of clinical oncology/college of American pathologists guideline recommendations for immunohistochemical testing of estrogen and progesterone receptors in breast cancer. J Clin Oncol 2010, 28:2784-2795.

16. Jordan VC: Tamoxifen: toxicities and drug resistance during the treatment and prevention of breast cancer. Annu Rev Pharmacol Toxicol 1995, 35:195-211.

17. Johnson MD, Zuo H, Lee KH, Trebley JP, Rae JM, Weatherman RV, Desta Z, Flockhart DA, Skaar TC: Pharmacological characterization of 4-hydroxy-Ndesmethyl tamoxifen, a novel active metabolite of tamoxifen. Breast Cancer Res Treat 2004, 85:151-159.

18. Stearns V, Johnson MD, Rae JM, Morocho A, Novielli A, Bhargava P, Hayes DF, Desta Z, Flockhart DA: Active tamoxifen metabolite plasma concentrations after coadministration of tamoxifen and the selective serotonin reuptake inhibitor paroxetine. J Natl Cancer Inst 2003, 95:1758-1764.

19. Pharoah PD, Abraham J, Caldas C: Re: CYP2D6 genotype and tamoxifen response in postmenopausal women with endocrine-responsive breast cancer: the breast international group 1-98 trial and Re: CYP2D6 and UGT2B7 genotype and risk of recurrence in tamoxifen-treated breast cancer patients. J Nat/ Cancer Inst 2012, 104:1263-1264. author reply 1266-1268.

20. Stanton $V$ Jr: Re: CYP2D6 genotype and tamoxifen response in postmenopausal women with endocrine-responsive breast cancer: the breast international group 1-98 trial. J Natl Cancer Inst 2012, 104:1265-1266. author reply 1266-1268.

21. Regan MM, Leyland-Jones B, Bouzyk M, Pagani O, Tang W, Kammler R, Dell'orto P, Biasi MO, Thürlimann B, Lyng MB, Ditzel HJ, Neven P, Debled M, Maibach R, Price KN, Gelber RD, Coates AS, Goldhirsch A, Rae JM, Viale G, Breast International Group (BIG) 1-98 Collaborative Group: CYP2D6 Genotype and tamoxifen response in postmenopausal women with endocrine-responsive breast cancer: the breast international group 1-98 trial. J Natl Cancer Inst 2012, 104:441-451.

22. Rae JM, Drury S, Hayes DF, Stearns V, Thibert JN, Haynes BP, Salter J, Sestak I, Cuzick J, Dowsett M: CYP2D6 and UGT2B7 genotype and risk of recurrence in tamoxifen-treated breast cancer patients. J Natl Cancer Inst 2012, 104:452-460.

23. Nakamura Y, Ratain MJ, Cox NJ, McLeod HL, Kroetz DL, Flockhart DA: Re: CYP2D6 genotype and tamoxifen response in postmenopausal women with endocrine-responsive breast cancer: the Breast International Group 1-98 trial. J Natl Cancer Inst 2012, 104:1264. author reply 1266-1268.

24. Kelly CM, Pritchard KI: CYP2D6 genotype as a marker for benefit of adjuvant tamoxifen in postmenopausal women: lessons learned. J Natl Cancer Inst 2012, 104:427-428.

25. Rae JM, Regan M, Leyland-Jones B, Hayes DF, Dowsett M: CYP2D6 genotype should not be used for deciding about tamoxifen therapy in postmenopausal breast cancer. J Clin Oncol 2013, 31:2753-2755.

26. Cuzick J, Ambroisine L, Davidson N, Jakesz R, Kaufmann M, Regan M, Sainsbury R: Use of luteinising-hormone-releasing hormone agonists as adjuvant treatment in premenopausal patients with hormone-receptorpositive breast cancer: a meta-analysis of individual patient data from randomised adjuvant trials. Lancet 2007, 369:1711-1723.

27. Davidson NE, O'Neill AM, Vukov AM, Osborne CK, Martino S, White DR, Abeloff MD: Chemoendocrine therapy for premenopausal women with axillary lymph node-positive, steroid hormone receptor-positive breast cancer: results from INT 0101 (E5188). J Clin Oncol 2005, 23:5973-5982.

28. Gnant M, Mlineritsch $B$, Schippinger $W$, Luschin-Ebengreuth $G$, Pöstlberger S, Menzel C, Jakesz R, Seifert M, Hubalek M, Bjelic-Radisic V, Samonigg H, Tausch C, Eidtmann H, Steger G, Kwasny W, Dubsky P, Fridrik M, Fitzal F, Stierer M, Rücklinger E, Greil R, Marth C, ABCSG-12 Trial Investigators: Endocrine therapy plus zoledronic acid in premenopausal breast cancer. N Engl J Med 2009, 360:679-691.

29. Gnant M, Mlineritsch B, Stoeger H, Luschin-Ebengreuth G, Heck D, Menzel C, Jakesz R, Seifert M, Hubalek M, Pristauz G, Bauernhofer T, Eidtmann $H_{\text {, }}$ Eiermann W, Steger G, Kwasny W, Dubsky P, Hochreiner G, Forsthuber EP, Fesl C, Greil R, Austrian Breast and Colorectal Cancer Study Group, Vienna, Austria: Adjuvant endocrine therapy plus zoledronic acid in premenopausal women with early-stage breast cancer: 62-month follow-up from the ABCSG-12 randomised trial. Lancet Oncol 2011, 12:631-641.

30. Pfeiler $G$, Königsberg R, FesI C, Mlineritsch B, Stoeger H, Singer CF, Pöstlberger S, Steger GG, Seifert M, Dubsky P, Taucher S, Samonigg H, Bjelic-Radisic V, Greil R, Marth C, Gnant M: Impact of body mass index on the efficacy of endocrine therapy in premenopausal patients with breast cancer: an analysis of the prospective ABCSG-12 trial. J Clin Oncol 2011, 29:2653-2659.

31. Hackshaw A, Baum M, Fornander T, Nordenskjold B, Nicolucci A, Monson K, Forsyth S, Reczko K, Johansson U, Fohlin H, Valentini M, Sainsbury R: Longterm effectiveness of adjuvant goserelin in premenopausal women with early breast cancer. J Natl Cancer Inst 2009, 101:341-349.

32. Dowsett $M$, Howell $A$ : Breast cancer: aromatase inhibitors take on tamoxifen. Nat Med 2002, 8:1341-1344.

33. Smith IE, Dowsett M: Aromatase inhibitors in breast cancer. N Engl J Med 2003, 348:2431-2442.

34. Lipton A, Santen RJ: Proceedings: medical adrenalectomy using Aminoglutethimide and Dexamethasone in advanced breast cancer. Cancer 1974, 33:503-512

35. Smith IE, Fitzharris BM, McKinna JA, Fahmy DR, Nash AG, Neville AM, Gazet JC, Ford HT, Powles TJ: Aminoglutethimide in treatment of metastatic breast carcinoma. Lancet 1978, 2:646-649.

36. Santen RJ, Worgul TJ, Samojlik E, Interrante A, Boucher AE, Lipton A, Harvey HA, White DS, Smart E, Cox C, Wells SA: A randomized trial comparing surgical adrenalectomy with aminoglutethimide plus hydrocortisone in women with advanced breast cancer. $N$ Engl J Med 1981, 305:545-551.

37. Jones AL, Powles TJ, Law M, Tidy A, Easton D, Coombes RC, Smith IE, McKinna JA, Nash A, Ford HT, Gazet JC: Adjuvant aminoglutethimide for postmenopausal patients with primary breast cancer: analysis at 8 years. J Clin Oncol 1992, 10:1547-1552.

38. Schmid M, Jakesz R, Samonigg H, Kubista E, Gnant M, Menzel C, Seifert M, Haider K, Taucher S, Mlineritsch B, Steindorfer P, Kwasny W, Stierer M, Tausch C, Fridrik M, Wette V, Steger G, Hausmaninger H: Randomized trial of tamoxifen versus tamoxifen plus aminoglutethimide as adjuvant treatment in postmenopausal breast cancer patients with hormone receptor-positive disease: Austrian breast and colorectal cancer study group trial 6. J Clin Oncol 2003, 21:984-990.

39. Miller WR, Bartlett J, Brodie AM, Brueggemeier RW, di Salle E, Lønning PE, Llombart A, Maass N, Maudelonde T, Sasano H, Goss PE: Aromatase inhibitors: are there differences between steroidal and nonsteroidal aromatase inhibitors and do they matter? Oncologist 2008, 13:829-837.

40. Geisler J, King N, Anker G, Ornati G, Di Salle E, Lonning PE, Dowsett M: In vivo inhibition of aromatization by exemestane, a novel irreversible aromatase inhibitor, in postmenopausal breast cancer patients. Clin Cancer Res 1998, 4:2089-2093.

41. Geisler J, Haynes B, Anker G, Dowsett M, Lonning PE: Influence of letrozole and anastrozole on total body aromatization and plasma estrogen levels in postmenopausal breast cancer patients evaluated in a randomized, cross-over study. J Clin Oncol 2002, 20:751-757.

42. Baum M, Budzar AU, Cuzick J, Forbes J, Houghton JH, Klijn JG, Sahmoud T: Anastrozole alone or in combination with tamoxifen versus tamoxifen alone for adjuvant treatment of postmenopausal women with early breast cancer: first results of the ATAC randomised trial. Lancet 2002, 359:2131-2139.

43. Breast International Group (BIG) 1-98 Collaborative Group, Thürlimann B, Keshaviah A, Coates AS, Mouridsen H, Mauriac L, Forbes JF, Paridaens R, Castiglione-Gertsch M, Gelber RD, Rabaglio M, Smith I, Wardley A, Price KN, 
Goldhirsch A: A comparison of letrozole and tamoxifen in postmenopausal women with early breast cancer. N Engl J Med 2005, 353:2747-2757.

44. Jones SE, Seynaeve C, Hasenburg A, Rae D, Vannetzel J, Paridaens R, Markopolous C, Hozumi Y, Putter H, Hille E, Kieback D, Asmar L, Smeets J, Urbanski R, Bartlett JM, van de Velde CJ: Results of the first planned analysis of the TEAM (tamoxifen exemestane adjuvant multinational) prospective randomized phase III trial in hormone sensitive postmenopausal early breast cancer [abstract 15]. Cancer Res 2009, 69:67s.

45. Coombes RC, Hall E, Gibson LJ, Paridaens R, Jassem J, Delozier T, Jones SE, Alvarez I, Bertelli G, Ortmann O, Coates AS, Bajetta E, Dodwell D, Coleman RE, Fallowfield LJ, Mickiewicz E, Andersen J, Lønning PE, Cocconi G, Stewart A, Stuart N, Snowdon CF, Carpentieri M, Massimini G, Bliss JM, van de Velde C, Intergroup Exemestane Study: A randomized trial of exemestane after two to three years of tamoxifen therapy in postmenopausal women with primary breast cancer. N Engl J Med 2004, 350:1081-1092.

46. Bliss JM, Kilburn LS, Coleman RE, Forbes JF, Coates AS, Jones SE, Jassem J, Delozier T, Andersen J, Paridaens R, van de Velde CJ, Lønning PE, Morden J, Reise J, Cisar L, Menschik T, Coombes RC: Disease-related outcomes with long-term follow-up: an updated analysis of the intergroup exemestane study. J Clin Oncol 2012, 30:709-717.

47. Kaufmann M, Jonat W, Hilfrich J, Eidtmann H, Gademann G, Zuna I, von Minckwitz G: Improved overall survival in postmenopausal women with early breast cancer after anastrozole initiated after treatment with tamoxifen compared with continued tamoxifen: the ARNO 95 Study. J Clin Oncol 2007, 25:2664-2670.

48. Dubsky PC, Jakesz R, Mlineritsch B, Pöstlberger S, Samonigg H, Kwasny W, Tausch C, Stöger H, Haider K, Fitzal F, Singer CF, Stierer M, Sevelda P, Luschin-Ebengreuth G, Taucher S, Rudas M, Bartsch R, Steger GG, Greil R, Filipcic L, Gnant M: Tamoxifen and anastrozole as a sequencing strategy: a randomized controlled trial in postmenopausal patients with endocrine-responsive early breast cancer from the Austrian breast and colorectal cancer study group. J Clin Oncol 2012, 30:722-728.

49. Boccardo F, Guglielmini P, Bordonaro R, Fini A, Massidda B, Porpiglia M, Roagna R, Serra P, Orzalesi L, Ucci G, Rubagotti A: Switching to anastrozole versus continued tamoxifen treatment of early breast cancer: long term results of the Italian tamoxifen anastrozole trial. Eur J Cancer 2013, 49:1546-1554.

50. Goss PE, Ingle JN, Martino S, Robert NJ, Muss HB, Piccart MJ, Castiglione M, Tu D, Shepherd LE, Pritchard Kl, Livingston RB, Davidson NE, Norton L, Perez EA, Abrams JS, Therasse P, Palmer MJ, Pater JL: A randomized trial of letrozole in postmenopausal women after five years of tamoxifen therapy for early-stage breast cancer. N Engl J Med 2003, 349:1793-1802.

51. Jakesz R, Greil R, Gnant M, Schmid M, Kwasny W, Kubista E, Mlineritsch B, Tausch C, Stierer M, Hofbauer F, Renner K, Dadak C, Rücklinger E, Samonigg $H$, Austrian Breast and Colorectal Cancer Study Group: Extended adjuvant therapy with anastrozole among postmenopausal breast cancer patients: results from the randomized Austrian breast and colorectal cancer study group trial 6a. J Natl Cancer Inst 2007, 99:1845-1853.

52. Mamounas EP, Jeong JH, Wickerham DL, Smith RE, Ganz PA, Land SR, Eisen A, Fehrenbacher L, Farrar WB, Atkins JN, Pajon ER, Vogel VG, Kroener JF, Hutchins LF, Robidoux A, Hoehn JL, Ingle JN, Geyer CE Jr, Costantino JP, Wolmark N: Benefit from exemestane as extended adjuvant therapy after 5 years of adjuvant tamoxifen: intention-to-treat analysis of the national surgical adjuvant breast and bowel project B-33 trial. J Clin Oncol 2008, 26:1965-1971.

53. Cuzick J, Sestak I, Baum M, Buzdar A, Howell A, Dowsett M, Forbes JF: Effect of anastrozole and tamoxifen as adjuvant treatment for early-stage breast cancer: 10-year analysis of the ATAC trial. Lancet Oncol 2010, 11:1135-1141.

54. Regan MM, Neven P, Giobbie-Hurder A, Goldhirsch A, Ejlertsen B, Mauriac L, Forbes JF, Smith I, Láng I, Wardley A, Rabaglio M, Price KN, Gelber RD, Coates AS, Thürlimann B, BIG 1-98 Collaborative Group; International Breast Cancer Study Group (IBCSG): Assessment of letrozole and tamoxifen alone and in sequence for postmenopausal women with steroid hormone receptor-positive breast cancer: the BIG 1-98 randomised clinical trial at 8.1 year median follow-up. Lancet Oncol 2011, 12:1101-1108.

55. van de Velde CJ, Rea D, Seynaeve C, Putter H, Hasenburg A, Vannetzel JM, Paridaens R, Markopoulos C, Hozumi Y, Hille ET, Kieback DG, Asmar L, Smeets J, Nortier JW, Hadji P, Bartlett JM, Jones SE: Adjuvant tamoxifen and exemestane in early breast cancer (TEAM): a randomised phase 3 trial. Lancet 2011, 377:321-331.

56. Jin H, Tu D, Zhao N, Shepherd LE, Goss PE: Longer-term outcomes of letrozole versus placebo after 5 years of tamoxifen in the NCIC CTG MA.17 trial: analyses adjusting for treatment crossover. J Clin Oncol 2012, 30:718-721.
57. Shao J, Chang M, Chow SC: Statistical inference for cancer trials with treatment switching. Stat Med 2005, 24:1783-1790.

58. Robins JM, Finkelstein DM: Correcting for noncompliance and dependent censoring in an AIDS clinical trial with inverse probability of censoring weighted (IPCW) log-rank tests. Biometrics 2000, 56:779-788.

59. Colleoni M, Giobbie-Hurder A, Regan MM, Thürlimann B, Mouridsen H, Mauriac L, Forbes JF, Paridaens R, Láng I, Smith I, Chirgwin J, Pienkowski T, Wardley A, Price KN, Gelber RD, Coates AS, Goldhirsch A: Analyses adjusting for selective crossover show improved overall survival with adjuvant letrozole compared with tamoxifen in the BIG 1-98 study. J Clin Oncol 2011, 29:1117-1124.

60. Howell A, Cuzick J, Baum M, Buzdar A, Dowsett M, Forbes JF, Hoctin-Boes G, Houghton J, Locker GY, Tobias JS: Results of the ATAC (arimidex, tamoxifen, alone or in combination) trial after completion of 5 years' adjuvant treatment for breast cancer. Lancet 2005, 365:60-62.

61. Coates AS, Keshaviah A, Thürlimann B, Mouridsen H, Mauriac L, Forbes JF, Paridaens R, Castiglione-Gertsch M, Gelber RD, Colleoni M, Láng I, Del Mastro L, Smith I, Chirgwin J, Nogaret JM, Pienkowski T, Wardley A, Jakobsen EH, Price $\mathrm{KN}$, Goldhirsch A: Five years of letrozole compared with tamoxifen as initial adjuvant therapy for postmenopausal women with endocrine-responsive early breast cancer: update of study BIG 1-98. J Clin Oncol 2007, 25:486-492.

62. on behalf of the ATAC Trialists' Group, Buzdar AU: Clinical features of joint symptoms observed in the arimidex, tamoxifen, alone or in combination (ATAC) trial [abstract 551]. Proc Am Soc Clin Oncol 2006, 24:551

63. Goss PE, Ingle JN, Martino S, Robert NJ, Muss HB, Piccart MJ, Castiglione M, Tu D, Shepherd LE, Pritchard Kl, Livingston RB, Davidson NE, Norton L, Perez EA, Abrams JS, Cameron DA, Palmer MJ, Pater JL: Randomized trial of letrozole following tamoxifen as extended adjuvant therapy in receptorpositive breast cancer: updated findings from NCIC CTG MA.17. J Natl Cancer Inst 2005, 97:1262-1271.

64. Mouridsen H, Giobbie-Hurder A, Goldhirsch A, Thürlimann B, Paridaens R, Smith I, Mauriac L, Forbes J, Price KN, Regan MM, Gelber RD, Coates AS, BIG 1-98 Collaborative Group: Letrozole therapy alone or in sequence with tamoxifen in women with breast cancer. N Engl J Med 2009, 361:766-776.

65. Eastell R, Adams JE, Coleman RE, Howell A, Hannon RA, Cuzick J, Mackey JR, Beckmann MW, Clack G: Effect of anastrozole on bone mineral density: 5year results from the anastrozole, tamoxifen, alone or in combination trial 18233230. J Clin Oncol 2008, 26:1051-1057.

66. Hadji P, Ziller M, Kieback DG, Dornoff W, Tessen HW, Menschik T, Kuck J, Melchert F, Hasenburg A: Effects of exemestane and tamoxifen on bone health within the tamoxifen exemestane adjuvant multicentre (TEAM) trial: results of a German, 12-month, prospective, randomised substudy. Ann Oncol 2009, 20:1203-1209.

67. Perez EA, Josse RG, Pritchard KI, Ingle JN, Martino S, Findlay BP, Shenkier TN, Tozer RG, Palmer MJ, Shepherd LE, Liu S, Tu D, Goss PE: Effect of letrozole versus placebo on bone mineral density in women with primary breast cancer completing 5 or more years of adjuvant tamoxifen: a companion study to NCIC CTG MA.17. J Clin Oncol 2006, 24:3629-3635.

68. Forbes JF, Cuzick J, Buzdar A, Howell A, Tobias JS, Baum M: Effect of anastrozole and tamoxifen as adjuvant treatment for early-stage breast cancer: 100-month analysis of the ATAC trial. Lancet Oncol 2008, 9:45-53.

69. Buzdar A, Howell A, Cuzick J, Wale C, Distler W, Hoctin-Boes G, Houghton J, Locker GY, Nabholtz JM: Comprehensive side-effect profile of anastrozole and tamoxifen as adjuvant treatment for early-stage breast cancer: longterm safety analysis of the ATAC trial. Lancet Oncol 2006, 7:633-643.

70. Coombes RC, Kilburn LS, Snowdon CF, Paridaens R, Coleman RE, Jones SE, Jassem J, Van de Velde CJ, Delozier T, Alvarez I, Del Mastro L, Ortmann O, Diedrich K, Coates AS, Bajetta E, Holmberg SB, Dodwell D, Mickiewicz E, Andersen J, Lønning PE, Cocconi G, Forbes J, Castiglione M, Stuart N, Stewart A, Fallowfield LJ, Bertelli G, Hall E, Bogle RG, Carpentieri M, et al: Survival and safety of exemestane versus tamoxifen after 2-3 years' tamoxifen treatment (intergroup exemestane study): a randomised controlled trial. Lancet 2007, 369:559-570.

71. Dent SF, Gaspo R, Kissner M, Pritchard Kl: Aromatase inhibitor therapy: toxicities and management strategies in the treatment of postmenopausal women with hormone-sensitive early breast cancer. Breast Cancer Res Treat 2011, 126:295-310.

72. Cheung AM, Tile L, Cardew S, Pruthi S, Robbins J, Tomlinson G, Kapral MK, Khosla S, Majumdar S, Erlandson M, Scher J, Hu H, Demaras A, Lickley L, Bordeleau L, Elser C, Ingle J, Richardson H, Goss PE: Bone density and structure in healthy postmenopausal women treated with exemestane 
for the primary prevention of breast cancer: a nested substudy of the MAP.3 randomised controlled trial. Lancet Oncol 2012, 13:275-284.

73. Gralow JR, Biermann JS, Farooki A, Fornier MN, Gagel RF, Kumar RN, Shapiro CL, Shields A, Smith MR, Srinivas S, Van Poznak CH: NCCN task force report: bone health in cancer care. J Natl Compr Canc Netw 2009, 7:S1-S32. quiz S33-S35.

74. Hadji P, Body JJ, Aapro MS, Brufsky A, Coleman RE, Guise T, Lipton A, Tubiana-Hulin M: Practical guidance for the management of aromatase inhibitor-associated bone loss. Ann Oncol 2008, 19:1407-1416.

75. Hillner BE, Ingle JN, Chlebowski RT, Gralow J, Yee GC, Janjan NA, Cauley JA, Blumenstein BA, Albain KS, Lipton A, American Society of Clinical Oncology, Brown S: American society of clinical oncology 2003 update on the role of bisphosphonates and bone health issues in women with breast cancer. J Clin Oncol 2003, 21:4042-4057.

76. Goss PE, Hadji P, Subar M, Abreu P, Thomsen T, Banke-Bochita J: Effects of steroidal and nonsteroidal aromatase inhibitors on markers of bone turnover in healthy postmenopausal women. Breast Cancer Res 2007, 9:R52.

77. McCloskey EV, Hannon RA, Lakner G, Fraser WD, Clack G, Miyamoto A, Finkelman RD, Eastell R: Effects of third generation aromatase inhibitors on bone health and other safety parameters: results of an open, randomised, multi-centre study of letrozole, exemestane and anastrozole in healthy postmenopausal women. Eur J Cancer 2007, 43:2523-2531.

78. Geisler J, Lønning PE, Krag LE, Løkkevik E, Risberg T, Hagen Al, Schlichting E, Lien EA, Ofjord ES, Eide GE, Polli A, di Salle E, Paolini J: Changes in bone and lipid metabolism in postmenopausal women with early breast cancer after terminating 2-year treatment with exemestane: a randomised, placebo-controlled study. Eur J Cancer 2006, 42:2968-2975.

79. On behalf of the Intergroup Exemestane Study, Coleman RE, Banks LM, Girgis SI, Vrdoljak E, Fox J, Cawthorn S, Patel A, Coombes RC, Bliss JM, Kilburn LS: Reversal of skeletal effects of endocrine treatments in the Intergroup Exemestane Study (IES). San Antonio, TX: Paper presented at: 31st Annual San Antonio Breast Cancer Symposium; 2008:1128.

80. Cuzick J, Sestak I, Cella D, Fallowfield L: Treatment-emergent endocrine symptoms and the risk of breast cancer recurrence: a retrospective analysis of the ATAC trial. Lancet Oncol 2008, 9:1143-1148.

81. Pritchard KI: Endocrine symptoms to predict risk of recurrence? Lancet Oncol 2008, 9:1117-1119.

82. Fontein DB, Seynaeve C, Hadji P, Hille ET, van de Water W, Putter H, Kranenbarg EM, Hasenburg A, Paridaens RJ, Vannetzel JM, Markopoulos C, Hozumi Y, Bartlett JM, Jones SE, Rea DW, Nortier JW, van de Velde CJ: Specific adverse events predict survival benefit in patients treated with tamoxifen or aromatase inhibitors: an international tamoxifen exemestane adjuvant multinational trial analysis. J Clin Oncol 2013, 31:2257-2264.

83. Huober J, Cole BF, Rabaglio M, Giobbie-Hurder A, Wu J, Ejlertsen B, Bonnefoi H, Forbes JF, Neven P, Láng I, Smith I, Wardley A, Price KN, Goldhirsch A, Coates AS, Colleoni M, Gelber RD, Thürlimann B, BIG 1-98 Collaborative and International Breast Cancer Study Groups: Symptoms of endocrine treatment and outcome in the BIG 1-98 study. Breast Cancer Res Treat 2014, 143:159-169.

84. Collins B, Mackenzie J, Stewart A, Bielajew C, Verma S: Cognitive effects of chemotherapy in post-menopausal breast cancer patients 1 year after treatment. Psychooncology 2009, 18:134-143.

85. Side effects revisited: women's experiences with aromatase inhibitors. A report from breast cancer action. http://bcation.org/uploads/PDF/AlReport.pdf.

86. Jenkins V, Shilling V, Fallowfield L, Howell A, Hutton S: Does hormone therapy for the treatment of breast cancer have a detrimental effect on memory and cognition? a pilot study. Psychooncology 2004, 13:61-66.

87. Bender CM, Sereika SM, Brufsky AM, Ryan CM, Vogel VG, Rastogi P, Cohen SM, Casillo FE, Berga SL: Memory impairments with adjuvant anastrozole versus tamoxifen in women with early-stage breast cancer. Menopause 2007, 14:995-998.

88. Phillips KA, Ribi K, Sun Z, Stephens A, Thompson A, Harvey V, Thürlimann B, Cardoso F, Pagani O, Coates AS, Goldhirsch A, Price KN, Gelber RD, Bernhard $\mathrm{J}$ : Cognitive function in postmenopausal women receiving adjuvant letrozole or tamoxifen for breast cancer in the BIG 1-98 randomized trial. Breast 2010, 19:388-395.

89. Phillips KA, Aldridge J, Ribi K, Sun Z, Thompson A, Harvey V, Thürlimann B, Cardoso F, Pagani O, Coates AS, Goldhirsch A, Price KN, Gelber RD, Bernhard $\mathrm{J}$ : Cognitive function in postmenopausal breast cancer patients one year after completing adjuvant endocrine therapy with letrozole and/or tamoxifen in the BIG 1-98 trial. Breast Cancer Res Treat 2011, 126:221-226.

90. Schilder CM, Eggens PC, Seynaeve C, Linn SC, Boogerd W, Gundy CM, Beex LV, Van Dam FS, Schagen SB: Neuropsychological functioning in postmenopausal breast cancer patients treated with tamoxifen or exemestane after AC-chemotherapy: cross-sectional findings from the neuropsychological TEAM-side study. Acta Oncol 2009, 48:76-85.

91. Schilder CM, Seynaeve C, Beex LV, Boogerd W, Linn SC, Gundy CM, Huizenga HM, Nortier JW, van de Velde CJ, van Dam FS, Schagen SB: Effects of tamoxifen and exemestane on cognitive functioning of postmenopausal patients with breast cancer: results from the neuropsychological side study of the tamoxifen and exemestane adjuvant multinational trial. J Clin Oncol 2010, 28:1294-1300.

92. Viale G, Giobbie-Hurder A, Regan MM, Coates AS, Mastropasqua MG, Dell'Orto P, Maiorano E, MacGrogan G, Braye SG, Ohlschlegel C, Neven P, Orosz Z, Olszewski WP, Knox F, Thürlimann B, Price KN, Castiglione-Gertsch M, Gelber RD, Gusterson BA, Goldhirsch A, Breast International Group Trial 1-98: Prognostic and predictive value of centrally reviewed Ki-67 labeling index in postmenopausal women with endocrine-responsive breast cancer: results from breast international group trial 1-98 comparing adjuvant tamoxifen with letrozole. J Clin Oncol 2008, 26:5569-5575.

93. Viale G, Regan MM, Dell'Orto P, Mastropasqua MG, Maiorano E, Rasmussen BB, MacGrogan G, Forbes JF, Paridaens RJ, Colleoni M, Láng I, Thürlimann B, Mouridsen H, Mauriac L, Gelber RD, Price KN, Goldhirsch A, Gusterson BA, Coates AS, BIG 1-98 Collaborative and International Breast Cancer Study Groups: Which patients benefit most from adjuvant aromatase inhibitors? Results using a composite measure of prognostic risk in the BIG 1-98 randomized trial. Ann Oncol 2011, 22:2201-2207.

94. Metzger O, Giobbie-Hurder A, Mallon E, Viale G, Winer E, Thürlimann B, Gelber RD, Colleoni M, Ejlertsen B, Bonnefoi H, Coates AS, Goldhirsch A, Gusterson B, BIG 1-98 Collaborative Group, and International Breast Cancer Study Group: Relative effectiveness of letrozole compared with tamoxifen for patients with lobular carcinoma in the BIG 1-98 trial [abstract]. Cancer Res 2012, 72:S1-1.

95. Ellis MJ, Coop A, Singh B, Mauriac L, Llombert-Cussac A, Jänicke F, Miller WR, Evans DB, Dugan M, Brady C, Quebe-Fehling E, Borgs M: Letrozole is more effective neoadjuvant endocrine therapy than tamoxifen for ErbB-1- and/or ErbB-2-positive, estrogen receptor-positive primary breast cancer: evidence from a phase III randomized trial. J Clin Oncol 2001, 19:3808-3816.

96. Smith IE, Dowsett M, Ebbs SR, Dixon JM, Skene A, Blohmer JU, Ashley SE, Francis S, Boeddinghaus I, Walsh G: Neoadjuvant treatment of postmenopausal breast cancer with anastrozole, tamoxifen, or both in combination: the immediate preoperative anastrozole, tamoxifen, or combined with tamoxifen (IMPACT) multicenter double-blind randomized trial. J Clin Oncol 2005, 23:5108-5116.

97. Ellis MJ, Tao Y, Young O, White S, Proia AD, Murray J, Renshaw L, Faratian D, Thomas J, Dowsett M, Krause A, Evans DB, Miller WR, Dixon JM: Estrogenindependent proliferation is present in estrogen-receptor HER2-positive primary breast cancer after neoadjuvant letrozole. J Clin Oncol 2006, 24:3019-3025

98. Bartlett JM, Brookes CL, Piper T, van de Velde CJ, Stocken D, Lyttle N, Hasenburg A, Quintayo MA, Kieback DG, Putter H, Markopoulos C, Kranenbarg EM, Mallon EA, Dirix LY, Seynaeve C, Rea DW: Do type 1 receptor tyrosine kinases inform treatment choice? a prospectively planned analysis of the TEAM trial. Br J Cancer 2013, 109:2453-2461.

99. Dowsett M, Allred C, Knox J, Quinn E, Salter J, Wale C, Cuzick J, Houghton J, Williams N, Mallon E, Bishop H, Ellis I, Larsimont D, Sasano H, Carder P, Cussac AL, Knox F, Speirs V, Forbes J, Buzdar A: Relationship between quantitative estrogen and progesterone receptor expression and human epidermal growth factor receptor 2 (HER-2) status with recurrence in the arimidex, tamoxifen, alone or in combination trial. J Clin Oncol 2008, 26:1059-1065.

100. Rasmussen BB, Regan MM, Lykkesfeldt AE, Dell'Orto P, Del Curto B, Henriksen KL, Mastropasqua MG, Price KN, Méry E, Lacroix-Triki M, Braye S, Altermatt HJ, Gelber RD, Castiglione-Gertsch M, Goldhirsch A, Gusterson BA, Thürlimann B, Coates AS, Viale G, BIG 1-98 Collaborative and International Breast Cancer Study Groups: Adjuvant letrozole versus tamoxifen according to centrally-assessed ERBB2 status for postmenopausal women with endocrine-responsive early breast cancer: supplementary results from the BIG 1-98 randomised trial. Lancet Oncol 2008, 9:23-28.

101. Kennecke HF, Olivotto IA, Speers C, Norris B, Chia SK, Bryce C, Gelmon KA: Late risk of relapse and mortality among postmenopausal women with estrogen responsive early breast cancer after 5 years of tamoxifen. Ann Oncol 2007, 18:45-51.

102. Ingle JN, Tu D, Pater JL, Muss HB, Martino S, Robert NJ, Piccart MJ, Castiglione M, Shepherd LE, Pritchard KI, Livingston RB, Davidson NE, Norton L, Perez EA, Abrams JS, Cameron DA, Palmer MJ, Goss PE: Intent-to- 
treat analysis of the placebo-controlled trial of letrozole for extended adjuvant therapy in early breast cancer: NCIC CTG MA.17. Ann Oncol 2008, 19:877-882.

103. Goss PE, Ingle JN, Martino S, Robert N, Muss H, Shepherd L, Pritchard Kl, Livingston RB, Davidson N, Perez EA, Cameron D, Whelan T, Palmer M, Tu D: Outcomes of women who were premenopausal at diagnosis of early stage breast cancer in the NCIC CTG MA17 trial [abstract]. Cancer Res 2009, 69:487s.

104. Ingle JN, Tu D, Pater JL, Martino S, Robert NJ, Muss HB, Piccart MJ, Castiglione M, Shepherd LE, Pritchard Kl, Livingston RB, Davidson NE, Norton L, Perez EA, Abrams JS, Cameron DA, Palmer MJ, Goss PE: Duration of letrozole treatment and outcomes in the placebo-controlled NCIC CTG MA.17 extended adjuvant therapy trial. Breast Cancer Res Treat 2006, 99:295-300

105. Goss PE, Ingle JN, Pater JL, Martino S, Robert NJ, Muss HB, Piccart MJ, Castiglione M, Shepherd LE, Pritchard KI, Livingston RB, Davidson NE, Norton L, Perez EA, Abrams JS, Cameron DA, Palmer MJ, Tu D: Late extended adjuvant treatment with letrozole improves outcome in women with early-stage breast cancer who complete 5 years of tamoxifen. J Clin Oncol 2008, 26:1948-1955.

106. Markopoulos C, Dafni U, Misitzis J, Zobolas V, Tzoracoleftherakis E, Koukouras D, Xepapadakis G, Papadiamantis J, Venizelos B, Antonopoulou Z, Gogas H: Extended adjuvant hormonal therapy with exemestane has no detrimental effect on the lipid profile of postmenopausal breast cancer patients: final results of the ATENA lipid substudy. Breast Cancer Res 2009, 11:R35.

107. Goss PE, Mamounas EP, Jakesz R, Markopoulos C, Dowsett M, Peto R, Godwin J, Davies C: Aromatase inhibitors (Als) versus not (placebo/ observation) as late extended adjuvant therapy for postmenopausal women with early stage breast cancer: overviews of randomized trials of Als after $\sim 5$ years of tamoxifen [abstract]. Cancer Res 2009, 69:733s.

108. Higgins MJ, Liedke PE, GosS PE: Extended adjuvant endocrine therapy in hormone dependent breast cancer: the paradigm of the NCIC-CTG MA.17/BIG 1-97 trial. Crit Rev Oncol Hematol 2013, 86:23-32.

109. Fisher B, Dignam J, Bryant J, DeGillis A, Wickerham DL, Wolmark N, Costantino J, Redmond C, Fisher ER, Bowman DM, Deschênes L, Dimitrov NV Margolese RG, Robidoux A, Shibata H, Terz J, Paterson AH, Feldman MI, Farrar W, Evans J, Lickley HL: Five versus more than five years of tamoxifen therapy for breast cancer patients with negative lymph nodes and estrogen receptor-positive tumors. J Natl Cancer Inst 1996, 88:1529-1542.

110. Tormey DC, Gray DC, Falkson HC, Eastern Cooperative Oncology Group: Postchemotherapy adjuvant tamoxifen therapy beyond five years in patients with lymph node-positive breast cancer. J Natl Cancer Inst 1996, 88:1828-1833.

111. Stewart HJ, Everington D, McDonald CC, Dewar JA, Hawkins RA, Prescott RJ, George WD, The Scottish Cancer Trials Breast Group: Randomised comparison of 5 years of adjuvant tamoxifen with continuous therapy for operable breast cancer. Br J Cancer 1996, 74:297-299.

112. Earl $H$, Gray R, Kerr D, Lee M: The optimal duration of adjuvant tamoxifen treatment for breast cancer remains uncertain: randomize into aTTom. Clin Oncol (R Coll Radiol) 1997, 9:141-143.

113. Davies C, Pan H, Godwin J, Gray R, Arriagada R, Raina V, Abraham M, Medeiros Alencar VH, Badran A, Bonfill X, Bradbury J, Clarke M, Collins R, Davis SR, Delmestri A, Forbes JF, Haddad P, Hou MF, Inbar M, Khaled H, Kielanowska J, Kwan WH, Mathew BS, Mittra I, Müller B, Nicolucci A, Peralta $O$, Pernas F, Petruzelka L, Pienkowski T, et al: Long-term effects of continuing adjuvant tamoxifen to 10 years versus stopping at 5 years after diagnosis of oestrogen receptor-positive breast cancer: ATLAS, a randomised trial. Lancet 2013, 381:805-816.
114. Gray RG, Rea D, Handley K, Bowden SJ, Perry P, Earl HM, Poole CJ, Bates T, Chetiyawardana S, Dewar JA, Fernando IN, Frieve R, Nicoll J, Rayter Z, Robinson A, Salman A, Yarnold J, Bathers S, Marshall A, Lee M, On behalf of the aTTom Collaborative Group: aTTom: long-term effects of continuing adjuvant tamoxifen to 10 years versus stopping at 5 in 6,953 women with early breast cancer. Chicago, IL: Paper presented at: 49th Annual Meeting of the American Society of Clinical Oncology; 2013. Abstract 5.

115. Bianchini G, Gianni L: An unmet need: tailoring extended adjuvant endocrine therapy. Br J Cancer 2013, 109:2951-2953.

\section{$10.1186 / \mathrm{bcr} 3636$}

Cite this article as: Schiavon and Smith: Status of adjuvant endocrine therapy for breast cancer. Breast Cancer Research 2014, 16:206 